\title{
The Esquilino Tales. Comunicare, valorizzare, rigenerare
}

\author{
Elena Ippoliti \\ Andrea Casale
}

Abstract

II saggio presenta l'esperienza The Esquilino Tales, condotta con gli studenti del Master in Comunicazione dei Beni Culturali della Sapienza Università di Roma, che si è proposta di valorizzare la complessità molteplice, eppure identitaria, dell'Esquilino, XV Rione di Roma.

Trattandosi di un Bene in cui sia l'insieme e sia le singole sue parti sono innanzitutto riconoscibili in quanto 'figure', si è partiti dal convincimento che una proposta efficace non potesse che muovere dalla specificità segnica dei luoghi. La sperimentazione ha perciò approfondito le pratiche della Rappresentazione, innovandole attraverso le tecniche dello storytelling, della gamification e dello storydoing, con l'obiettivo di mettere a punto, allinterno di un'ampia gamma di linguaggi grafico-visuali, una strategia di comunicazione. Strategia che si è proposta di attivare tra i visitatori/cittadini e Esquilino/ città modalità attive di esplorazione quali prime azioni di valorizzazione e di rigenerazione urbana da cui partire per il riscatto delle nostre città.

Parole chiave

linguaggi grafici, rappresentazioni di città, gamification, storytelling, storydoing.

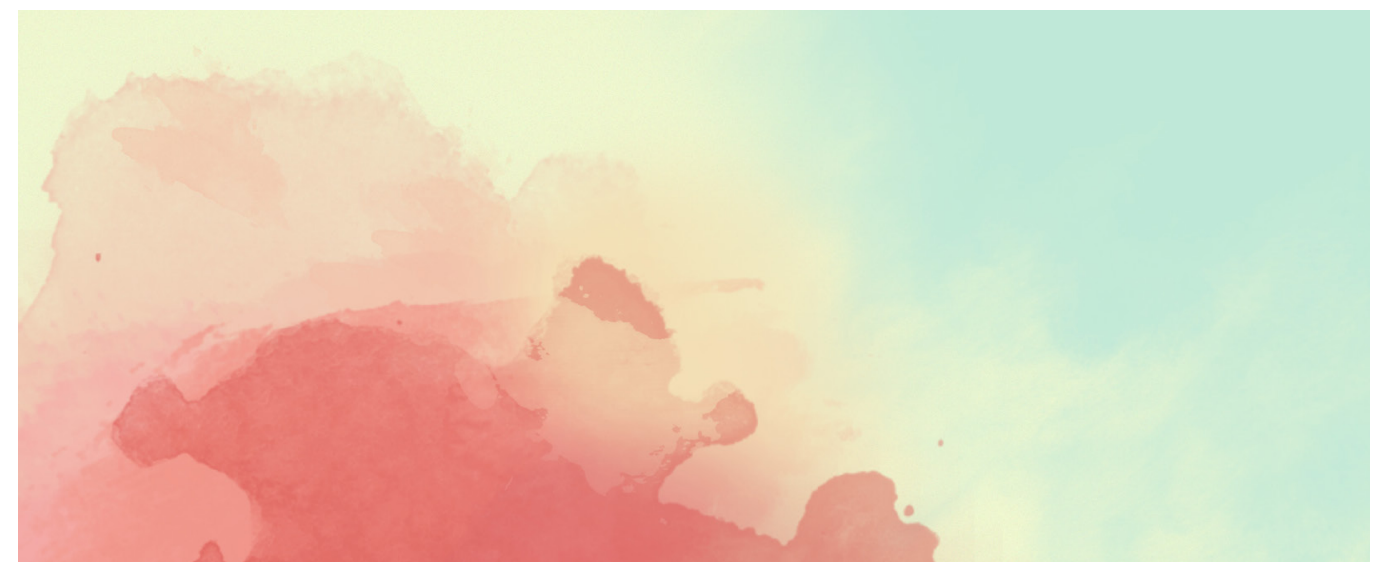




\section{Premessa}

Ciò che rende realmente unico il patrimonio culturale italiano è quel "continuum fra i monumenti, le città, i cittadini" perché, secondo l'interpretazione di Salvatore Settis, è proprio in quello straordinario continuum fra le opere 'alte' e il tessuto connettivo delle città che le ospitano il "nostro bene culturale più prezioso" [Settis 2002, p. I0].

Una consapevolezza profonda per il nostro Paese che da sempre, fin dalla definizione di bene culturale, considerare il patrimonio - materiale e immateriale - come bene sistemico, ovvero espressione dell'insieme di connessioni qualitative e quantitative tra i singoli beni e tra questi e il contesto di riferimento. Un'idea di patrimonio sistemico da cui si è originata anche una cultura della valorizzazione "nella quale il valore di ogni singolo monumento od oggetto d'arte risulta non dal suo isolamento, ma dal suo innestarsi in un vitale contesto" [Settis 2002, p. 15].

Una consapevolezza partecipe del profondo rinnovamento che, in particolare negli ultimi anni [MiBACT 20I4], ha riguardato il Museo, la sua missione e il fondamentale ruolo che può svolgere nella promozione dell'educazione e del progresso scientifico, della diversità culturale e naturale, dello sviluppo sostenibile e del dialogo interculturale [UNESCO 20 I5]. Un rinnovamento che ha riguardato sia gli 'oggetti' della 'collezione' [Desvallées, Mairesse 20 I 0, p. 26] e sia gli spazi museali, ampliandosi i primi e dilatandosi i secondi per ricomprendere le pratiche e i saperi, i luoghi culturali ad essi connessi e le comunità che si riconoscono in quel patrimonio culturale [UNESCO 2003]. Un Museo che ha perciò rivolto lo sguardo al di fuori di esso, rivalutando il patrimonio culturale diffuso nelle città e le comunità che le abitano attraverso il Museo Diffuso [Mottola Molfino 2007], una particolare fattispecie di museo dove è ancora più necessario lavorare sul sistema, cioè sulle connessioni per progettare "percorsi di senso, ben focalizzati in ambiti territoriali specifici, in modo che [...] non sia semplicemente un passare in rassegna una serie di capolavori o di monumenti, ma si traduca in un cammino storicamente e culturalmente coerente, $\mathrm{O}$ in molti possibili cammini paralleli" [Bray 20 I3].

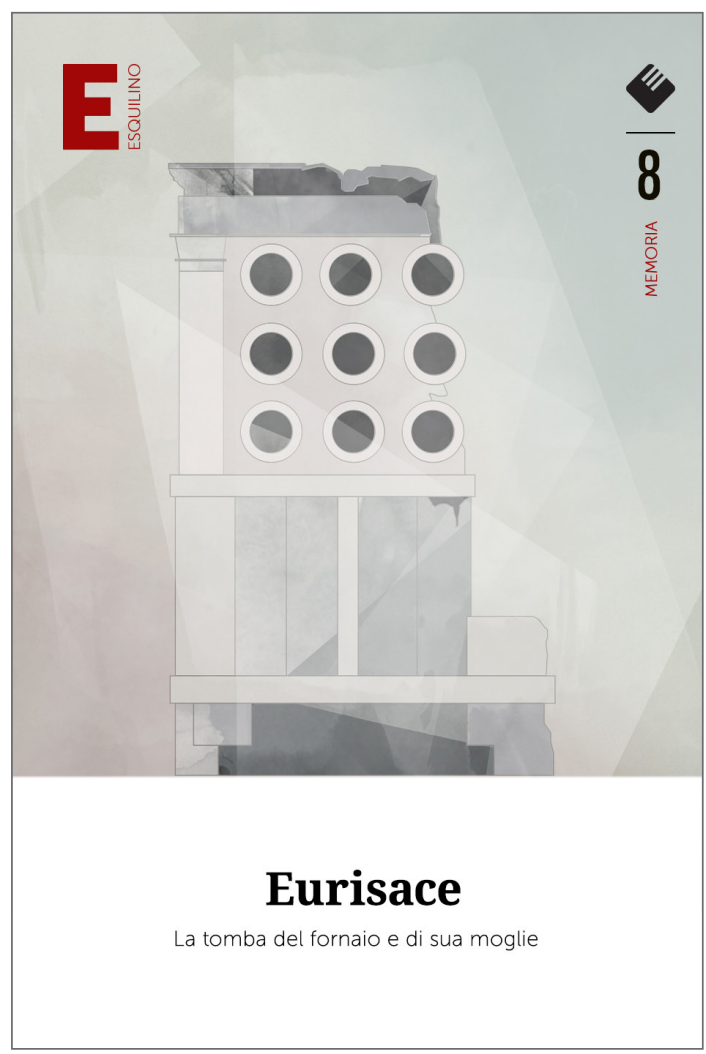


Promuovere la comunicazione di tali beni significa perciò lavorare sulle possibili connessioni, con un meccanismo in fondo molto simile a quello delle guide 'moderne' che, dalla prima metà dell'800, emanciparono il grande pubblico consentendogli di affrontare individualmente e in modo autodiretto il proprio viaggio. Particolari dispositivi dove, scomparso l'autore, avanzano in primo piano i luoghi che sono offerti al 'lettore/viaggiatore' per mezzo degli itinerari possibili [Ragonese 20 I0] e dove la trama tessuta tra luoghi e viaggiatore va a costruire un'attitudine all'esperienza del viaggio, reale o virtuale [Mangani 2007]. Un meccanismo che le guide 'moderne' non inventano, ma che derivano dalle diverse messe in forma dello spazio abitato - atlanti, mappe, carte, itinerari ecc. - e che poi, più di recente, è rinnovato dal cinema [Bruno 2006].

È nel quadro di queste riflessioni che è stata condotta l'esperienza The Esquilino Tales [I] che si è proposta di valorizzare la complessità molteplice, eppure identitaria, dell'Esquilino, XV Rione di Roma, sperimentando diverse forme e accezioni in cui è possibile declinare la Rappresentazione e le relative connessioni.

Trattandosi di un 'bene' che rientra in una definizione estesa di 'architettura', dove sia l'insieme e sia le singole sue parti sono cioè innanzitutto riconoscibili in quanto 'figure', si è partiti dal convincimento che una proposta di fruizione efficace non potesse che muovere dalla specificità segnica dei luoghi. La sperimentazione ha perciò approfondito le pratiche della Rappresentazione, innovandole attraverso le tecniche dello storytelling, della gamification e dello storydoing, con l'obiettivo di mettere a punto, all'interno di un'ampia gamma di linguaggi grafico-visuali, una strategia di comunicazione. Strategia che si è proposta di attivare tra i visitatori/cittadini e Esquilino/città modalità attive di esplorazione quali prime azioni di valorizzazione e di rigenerazione urbana da cui partire per il riscatto delle nostre città [2].

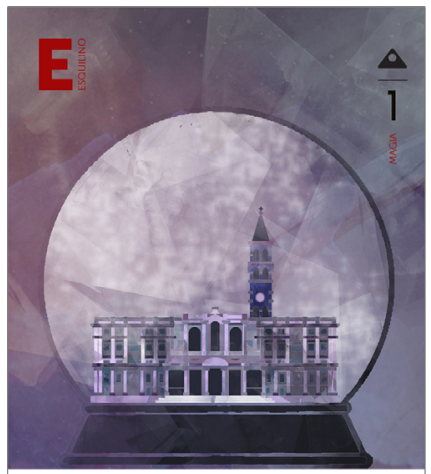

La neve a Santa Maria Maggiore gni 5 agosto il miracolo della neve

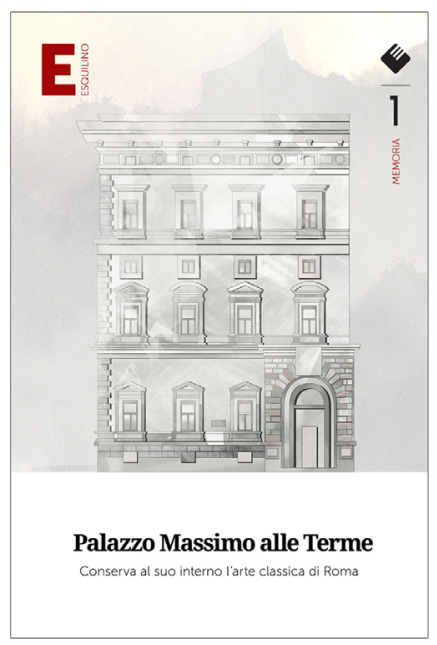

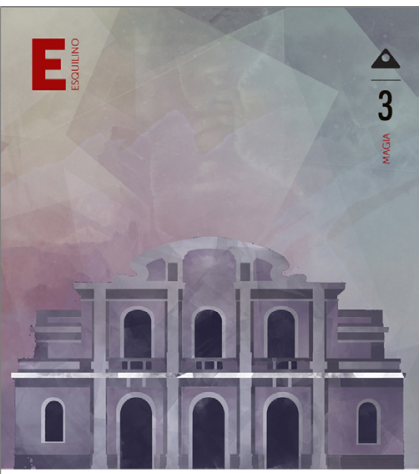

Teatro Ambra Jovinelli Larchitettura in stlle liberty nel cuore dell' Esquilino

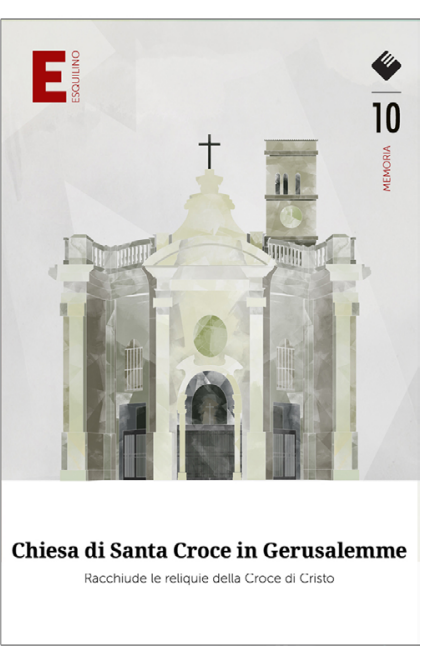


Fig. 3. Alcune carte rappresentative delle visua Passaggio e Contaminazione:"Stazione Termini. zone. Stazione Termin mondo" (realizzazione mondo" (reallzzazione di Maggiore. Acquedotto monumentale e Porta di Roma" (realizzazione di Angela Moschetti); " dinosauro della Stazione Termini. Nomi bizzarri pe architetture moderne (realizzazione di Simone Amarante);"Obelischi. Snodi eleganti nella pianta urbana di Roma" (realizzazione di Margherita Stisi).
Un'esperienza che, a nostro parere, rientra a pieno titolo nell'ambito più generale delle 'rappresentazioni di città', particolare famiglia di rappresentazioni che presenta un'amplissima gamma di tipi e variazioni ricorrendo a tutta l'estensione delle convenzioni rappresentative - dalla figura al segno, dal concetto alla verosimiglianza - ma che sono tutte accomunate dall'essere dispositivi emozionali. Una capacità emotiva per suggerire storie e interpretazioni che è tutt'oggi presente nelle rappresentazioni di città, seppur con forme mutate e innovate dai nuovi media.
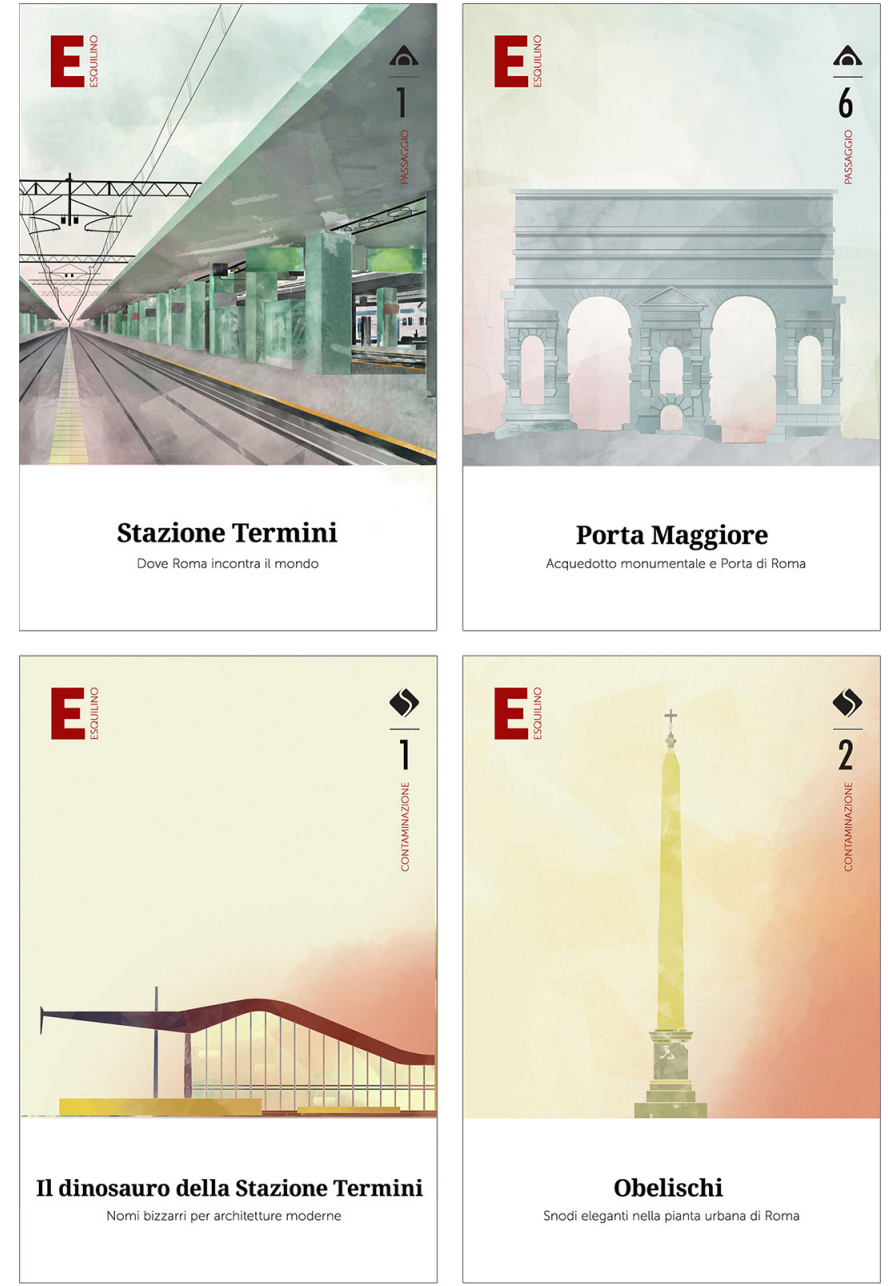

The Esquilino tales: il gioco

Nel 2020 Roma Capitale d'Italia compie I50 anni e da questa ricorrenza ha preso le mosse il progetto di comunicazione del Museo Diffuso The Esquilino Tales, il Rione dove si avviò l'edificazione di un intero quartiere in modo da adeguare la città, che allora aveva poco più di 200.000 abitanti, al ruolo di Capitale.

Questa l'occasione per esplorare un'area che custodisce importanti presenze della storia, da quella millenaria della città eterna a quella più recente d'Italia, ed è caratterizzata per la densità di luoghi di pregio storico, architettonico, archeologico, culturale, sociale, emozionale ma che, seppur al centro di Roma, è per lo più sconosciuta non solo ai turisti ma anche ai cittadini romani. Una realtà urbana stratificata che nel corso della sua storia ha saputo riconfigurarsi per adattarsi ai processi di crescita e trasformazione fisica e a quelli conseguenti di migrazione e globalizzazione, connotata dalla varietà sia dello spazio costruito e sia delle popolazioni che lo abitano: una molteplicità di città, più che una sola città. 
Fig. 4. Le varie prove iniziali e i riferimenti carte napoletane e francesi (in alto), le carte collezionabili Magic:The Gathering, (al centro), la piattaforma gaming Gris anche applicata alla tomba di Eurisace.
Una realtà complessa ed eterogenea impossibile da poter essere descritta secondo un solo punto di vista, da una parte, e l'esigenza di una comunicazione sintetica e coinvolgente che induca il 'visitatore' ad una partecipazione attiva, dall'altra, ha convinto di individuare nella tecnica della gamification la struttura su cui ancorare il progetto di comunicazione.

Alcune esperienze condotte negli ultimi tempi nell'ambito della comunicazione dei beni culturali hanno dimostrato come il gioco sia un modo efficace anche per avvicinare il fruitore al patrimonio. L'ambiente emozionale del gioco, riuscendo ad attivare un rapporto d'interrelazione attiva, facilita infatti i processi di apprendimento, e questo perché "Play is a very serious matter [...] It is an expression of our creativity; and creativity is at the very root of our ability to learn, to cope, and to become whatever we may be", [Rogers, Sharapan 1994, p. I3]. E, come
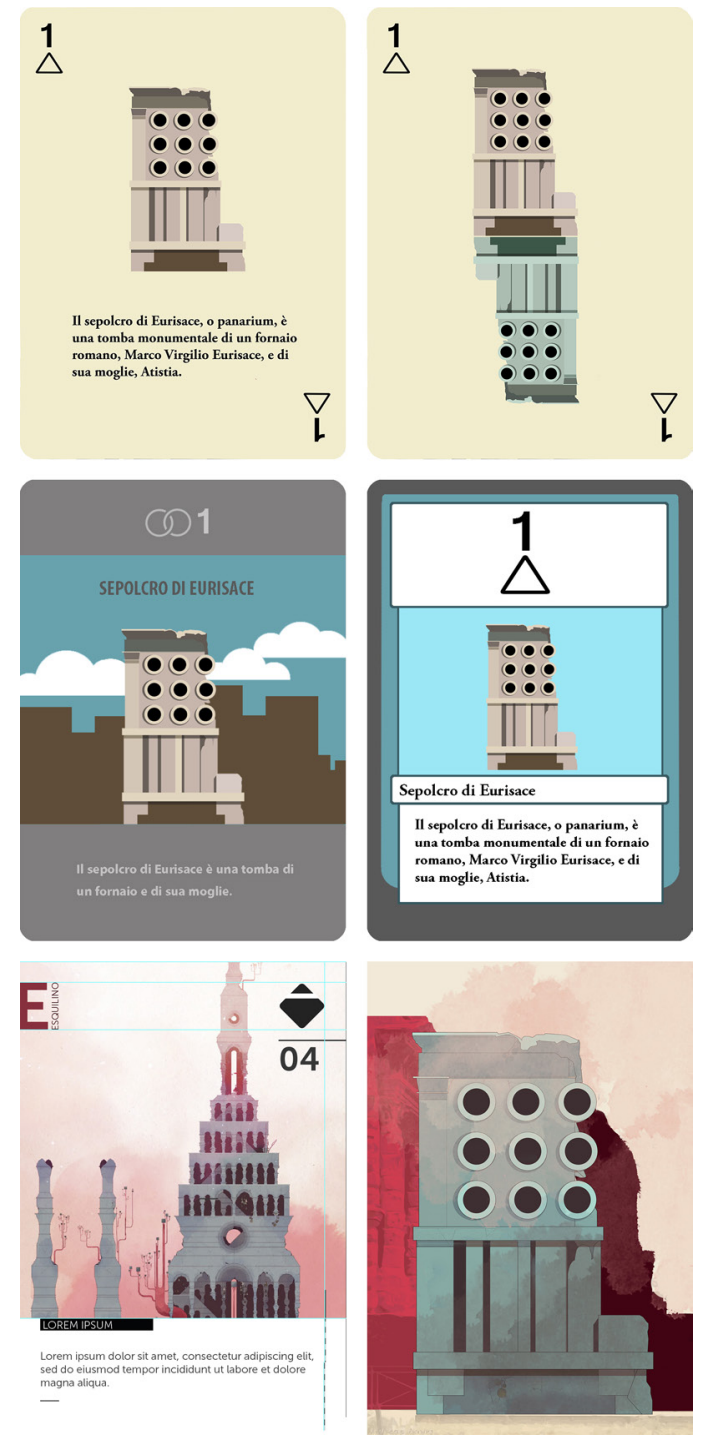

ben sanno i pedagoghi, nulla è più serio del gioco che è indispensabile all'individuo e anche alla collettività 'per il 'senso' che contiene, per il significato, per il valore espressivo, per i legami spirituali e sociali che crea, insomma in quanto funzione culturale" [Huizinga 1939, p. 7]. Scartata per diversi motivi l'ipotesi del video-gioco [3], dopo un'analisi dei giochi da tavolo più comuni [4], la scelta è ricaduta sulle carte da gioco collezionabili perché, come dimostrato di recente, combinando la metodica di gioco con la passione per il collezionismo questa particolare connessione gli attribuisce una capacità di diffondersi viralmente, cioè di autopromuoversi. 
Il concept del progetto di comunicazione prevede che ogni realtà urbana sia descritta attraverso un insieme di 40 carte (mazzo), articolato in quattro famiglie (dieci carte numerate da I a I0) cui è demandata una particolare tematica narrativa (itinerario). Seppur sperimentato solo sul Rione Esquilino, il progetto è impostato in modo tale da essere replicato, adeguatamente customizzato, su porzioni urbane diverse dotate di caratteristiche riconoscibili, condizione che favorisce anch'essa la diffusione del gioco attraverso la 'proliferazione' dei mazzi di carte.

Questa semplice struttura e le relative connessioni - carta/famiglia/mazzo/mazzi - trasforma perciò le carte in oggetti da collezione il che, grazie alla facilità di diffusione di queste, e alla competizione tra i giocatori che è alla base di ogni gioco, è un'ulteriore spinta all'interazione per la necessità degli scambi.

Fig. 5. I quattro sfondi corrispondenti alle quattro visuali narrative ognuno caratterizzato da una prevalente tonalità cromatica: viola/ blu per Magia, grigio per Memoria, verde/petrolio per Passaggio, arancio/ ocra per Contaminazione (realizzazione di Simone Amarante).
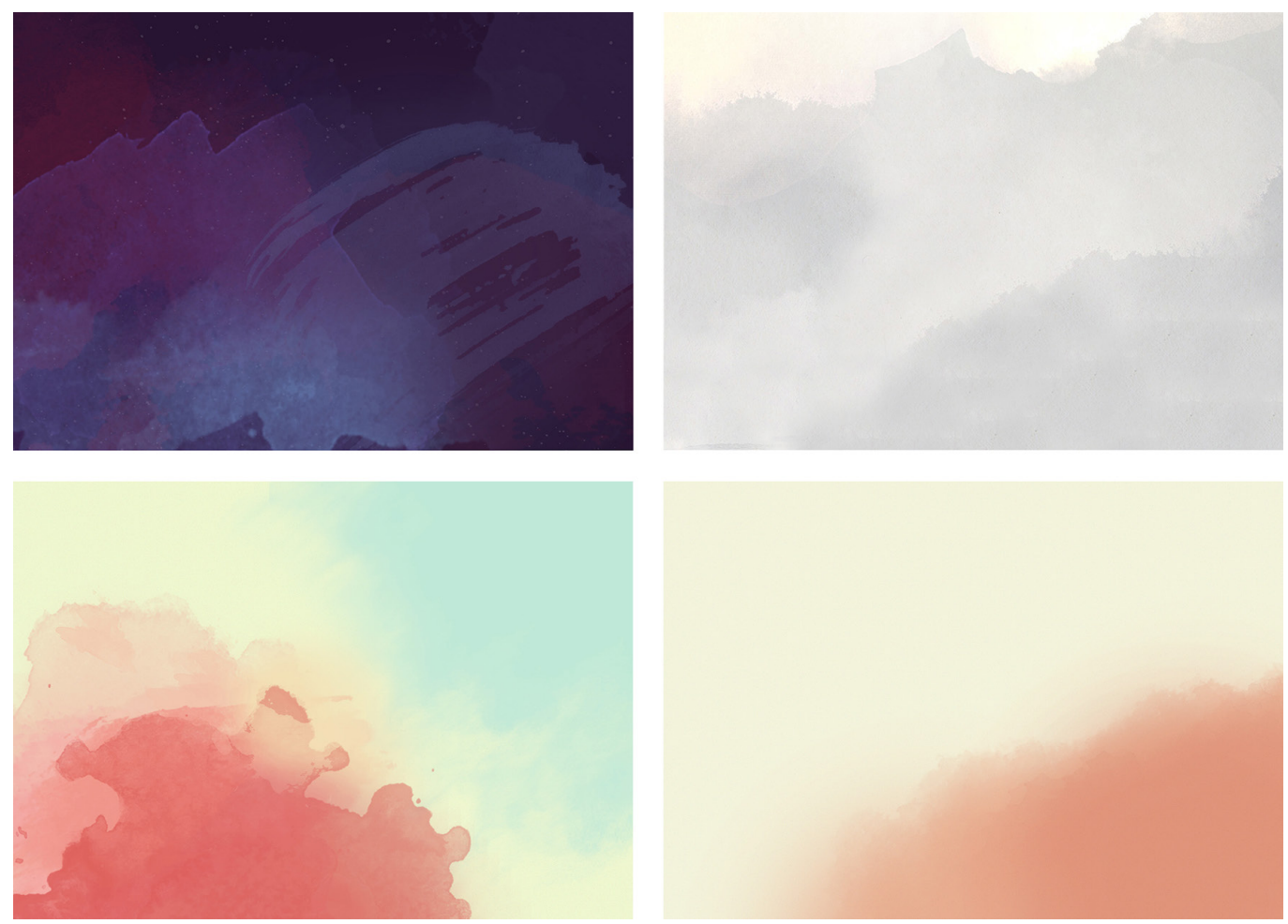

Per favorire l'esperienza di visita al patrimonio culturale custodito nelle città, le regole del gioco prevedono che il giocatore possa aumentare la potenza delle proprie carte quando interloquisce con un contenuto culturale, prevedendo incrementi di potenza via via crescenti a seconda dei differenti modi di accesso e di azioni: a distanza (attraverso QR code o app o sito web), in presenza attraverso una visita, completando di un itinerario tra quelli proposti ecc.

Fissato l'obbiettivo da raggiungere, i giocatori potranno così mettere in atto strategie diverse per guadagnare, singolarmente $\mathrm{o}$ in squadra, potenza attraverso la relazione con il bene culturale, mentre le regole del gioco prevedono che i giocatori personalizzino ogni singola partita stabilendo alcune variazioni del mazzo da completare, potendo modificare la composizione di default con la sostituzione di alcune singole carte, fermo restando famiglia e numero. 

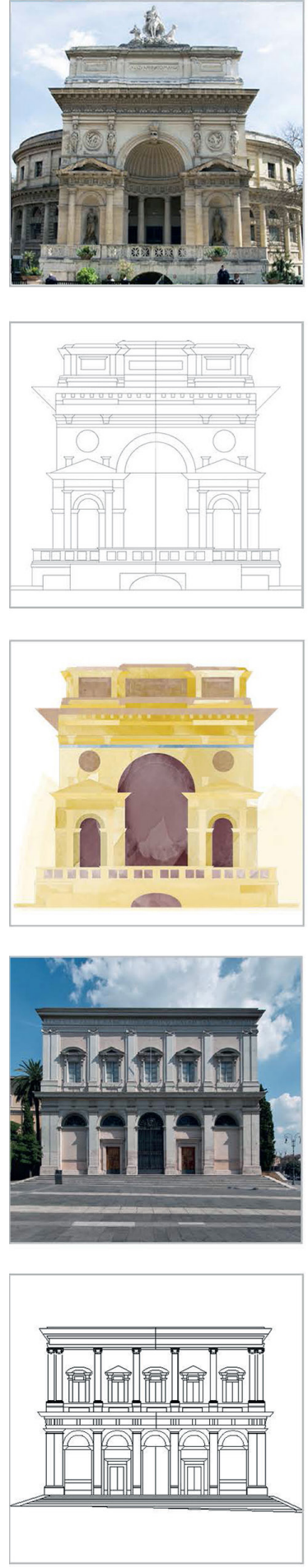

Fig. 6. II procedimento per la costruzione

delle carte: la costruzione della "figura", a partire alla documentazione fotografica attraverso il ricalco e alcuni particolari "pennelli", poi inserita nello sfondo della visuale. Nella figura l'Aquario ro-

mano e la Scala Santa del

aterano (realizzazione James Douch).

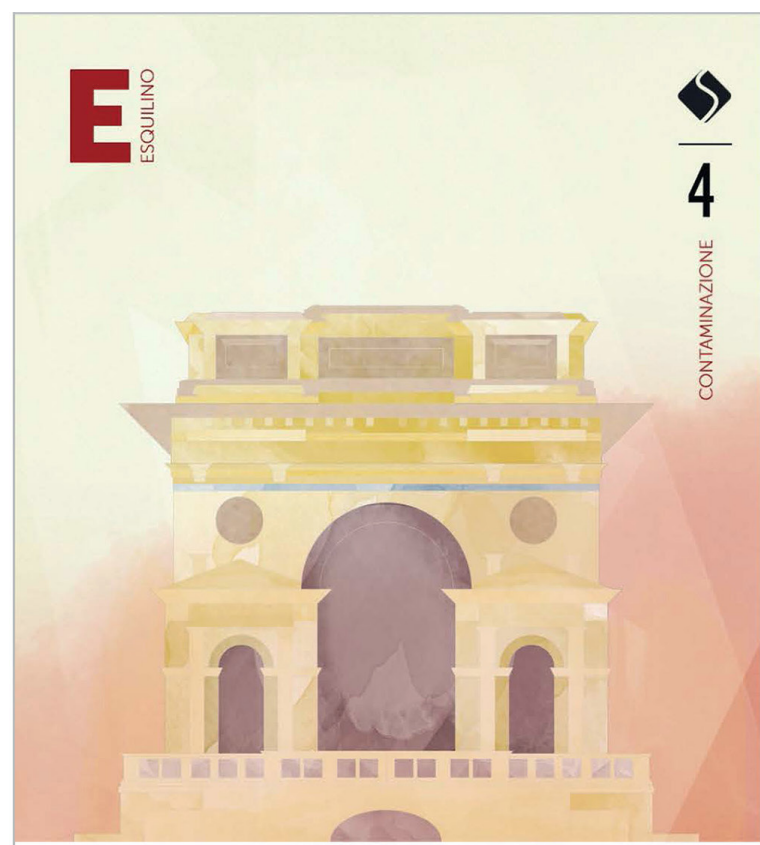

\section{Acquario romano}

La sfortunata disavventura di un edificio che

voleva essere parigino

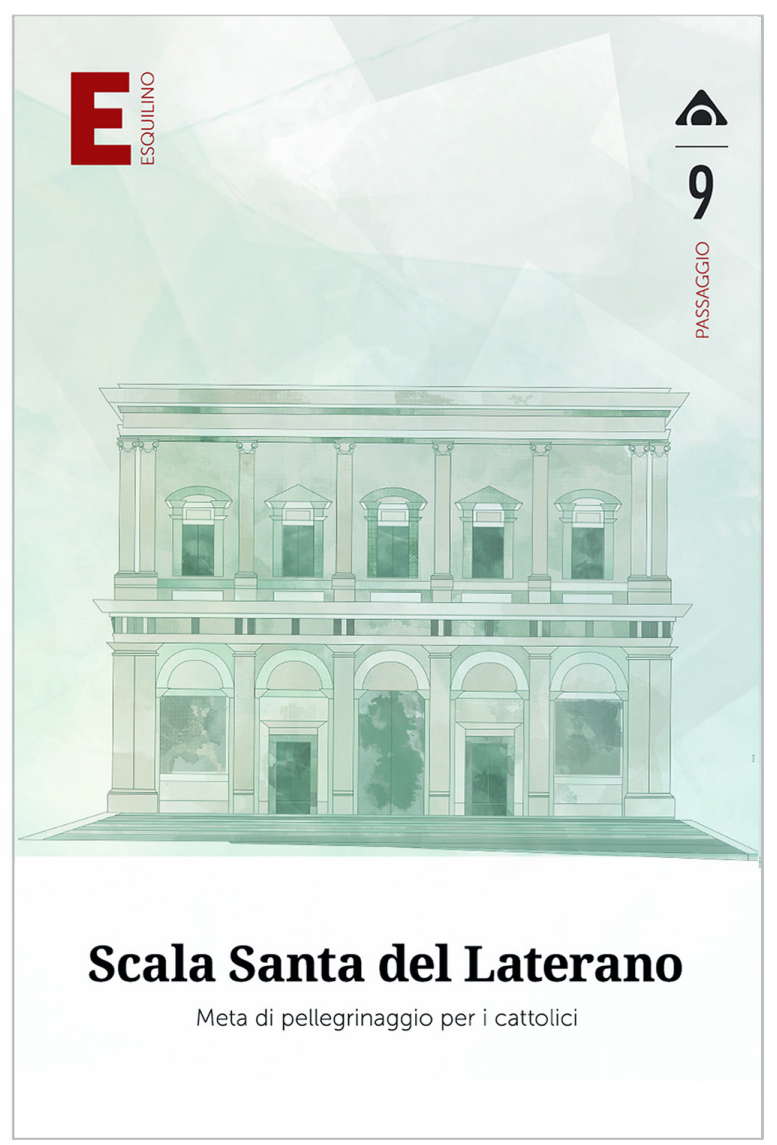




\section{The Esquilino Tales: il sistema di rappresentazioni}

Seppur il fulcro del progetto è nella singola carta (analogica e nelle sue variazioni digitali, con il ruolo d'interfaccia per l'accesso ai contenuti culturali (fig. I), il gioco è strutturato in modo che preferibilmente si scopra l'Esquilino seguendo le carte di una medesima famiglia, cioè una particolare visuale di lettura tra le quattro proposte da ogni mazzo. Visuale che realizza la connessione tra i singoli punti d'interesse (luoghi e storie che questi condensano) descritti da ogni carta per ricomporre uno specifico itinerario di visita.

Perciò, dopo un'attenta analisi del patrimonio materiale e immateriale dell'Esquilino, le quattro visuali secondo cui si sono raggruppati i punti di interesse sono state: la Magia, la Memoria, il Passaggio e la Contaminazione (figg. 2, 3).

Visuali che, come è facile capire, rappresentano categorie e qualità con un tale livello di generalizzazione da poter essere utilizzate proficuamente nella descrizione di altre realtà urbane, in quanto più che essere relazionate a quel particolare 'oggetto' fanno riferimento ad una particolare 'esperienza' che può essere vissuta attraversando i luoghi urbani: per una veduta inaspettata, per la dimensione onirica di una storia, per la fascinazione di uno spettacolo o di un concerto, per il godimento estetico di un'opera d'arte, per il ricordo di una storia passata, per la rievocazione di una storia recente, per la transizione tra un'epoca ed un'altra fisicamente esperita attraversando una città, per la connessione tra luoghi apparentemente diversi, per l'evidenza della multiculturalità nella contemporaneità, per la stratificazione che condensa uno spazio urbano, per la coesistenza sempre stata di sacro e profano ecc.

Definita la struttura del gioco nonché le principali regole, si è passati alla progettazione degli elementi grafici - figure, colori, sfondi, simboli, caratteri, layout - in modo che concorressero concordemente ad orientare i giocatori che si avviano ad intraprendere il viaggio attraverso The Esquilino Tales.

Perciò ogni luogo, e la storia ad esso associata, è rappresentato da una figura, mentre la visuale narrativa (Magia, Memoria, Passaggio, Contaminazione) è affidata sia alla palette di colori e sia ad un simbolo (seme).

Fig. 7. I "semi"' la costruzione degli ideogrammi rappresentativi delle quattro famiglie, ovvero delle quattro visuali narrative.
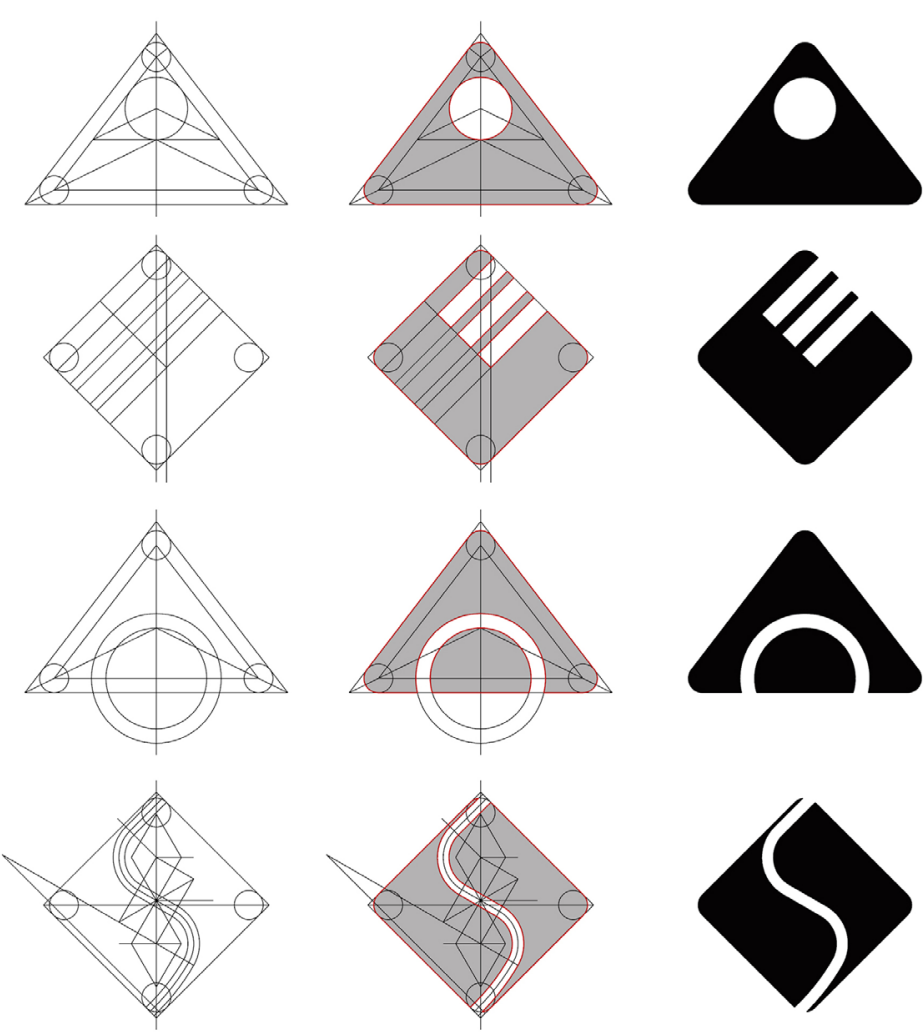
Per le figure l'obiettivo è stato quello di definire uno stile riconoscibile per cui, dopo diverse sperimentazioni [5] (fig. 4), si è deciso che queste, prive di contorni, dovessero emergere dall'accostamento di forme geometriche, perlopiù regolari, utilizzando solo toni di colori piatti, scelti all'interno di una medesima tonalità cromatica, e simulando in ambiente digitale l'uso dell'acquerello con pennelli di diverse dimensioni. II passo successivo è stato quello di associare una prevalente tonalità cromatica ad ognuna delle visuali narrative (viola/blu per Magia, grigio per Memoria, verde/petrolio per Passaggio, arancio/ocra per Contaminazione) per poi passare all'elaborazione dei quattro corrispondenti sfondi (fig. 5), questi caratterizzati da forme morbide e sinuose e che, a meno di puntuali modifiche, sono stati adottati per le carte appartenenti alla medesima famiglia (fig. 6).

Si è poi passati alla progettazione della grafica dei diversi semi (fig. 7), decidendo per una stilizzazione ideogrammatica che fosse espressiva delle quattro visuali, caratterizzate però da uniformità iconografica per forme (triangolo, quadrato, cerchio e angoli stondati) e colore (nero).

A seguire, sempre nell'ottica di non disorientare il giocatore, è stato definito il layout per la disposizione degli elementi grafici nello spazio compositivo delle carte di dimensioni $8 \times 12$ cm (fig. 8). Sul recto di queste, in alto a sinistra sono disposte la 'E' e il testo 'Esquilino' bilanciate, sulla destra, dal seme, seguito dal numero e dal nome testuale della visuale. In verticale lo spazio della carta è suddiviso in due parti: in alto è la figura posta sullo sfondo, mentre in basso è lasciata una fascia bianca in cui è disposto in asse il nome del luogo (carattere con grazie, grassetto e un corpo di dimensioni tali da essere facilmente leggibile) e un sottotitolo che anticipa la storia (carattere bastoni e un corpo notevolmente più piccolo).
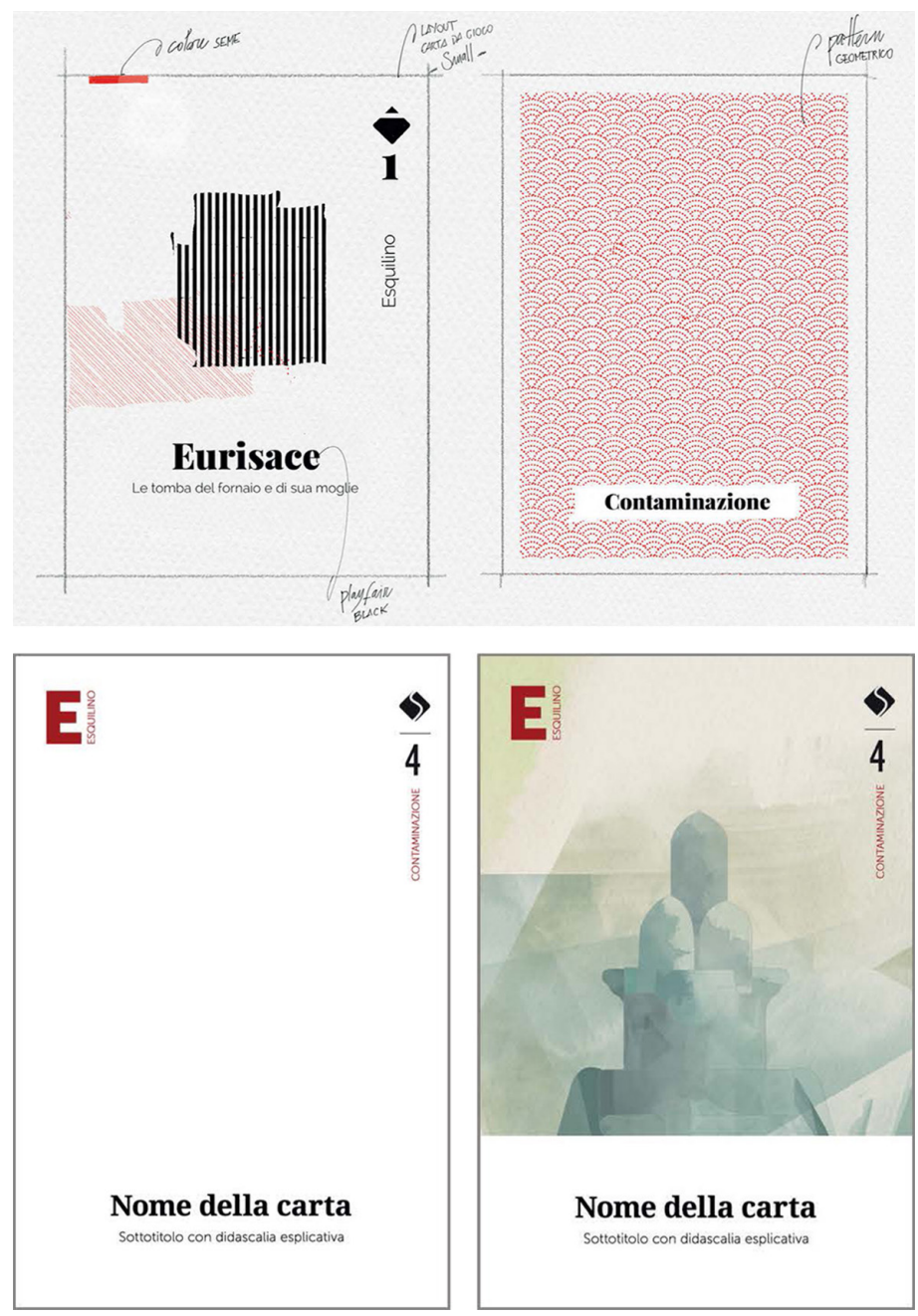
Fig. 9. La composizione del verso della carta

(realizzazione di Simone Amarante).
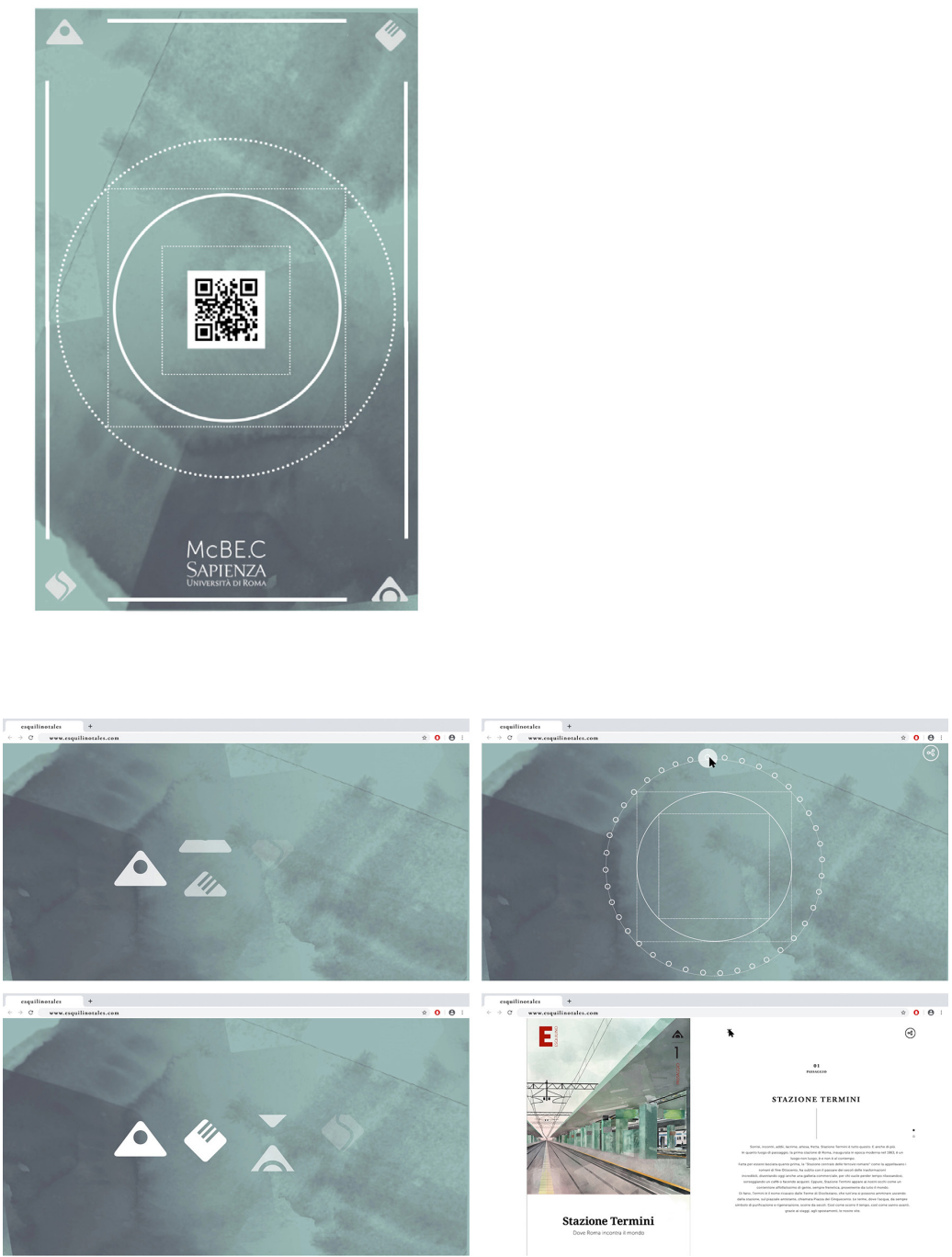

Stazione Termini
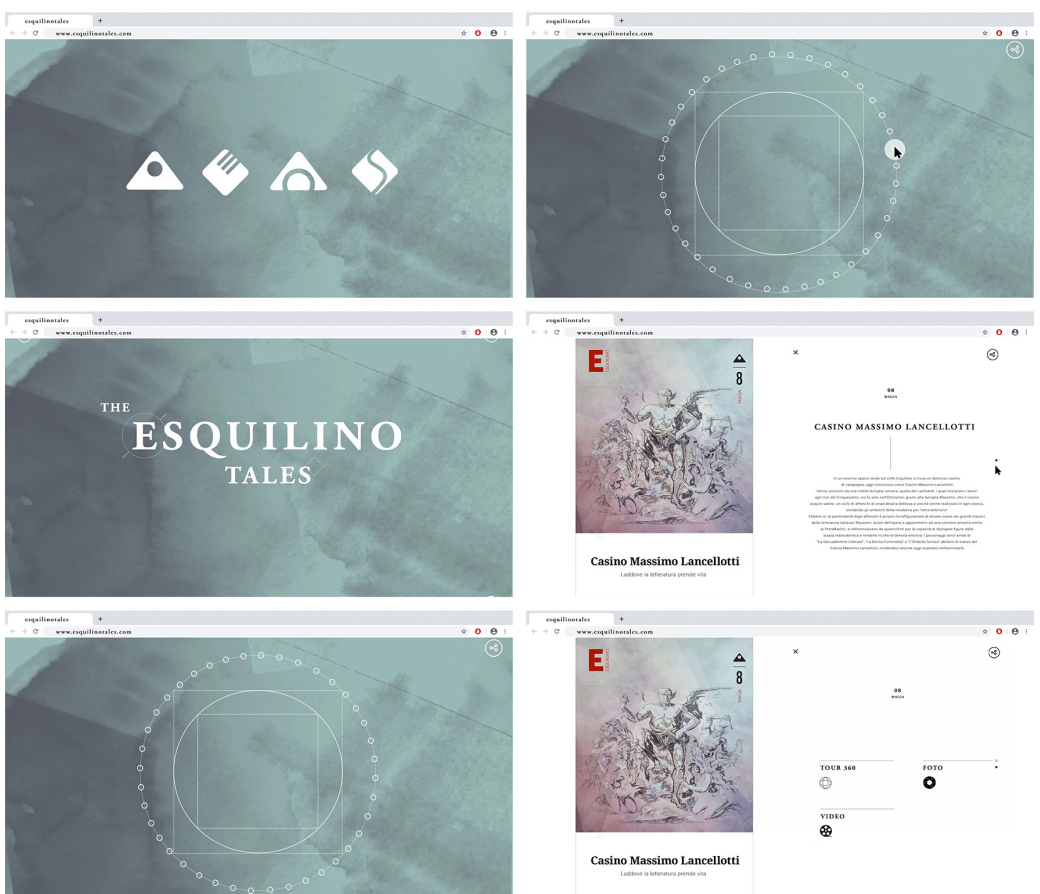

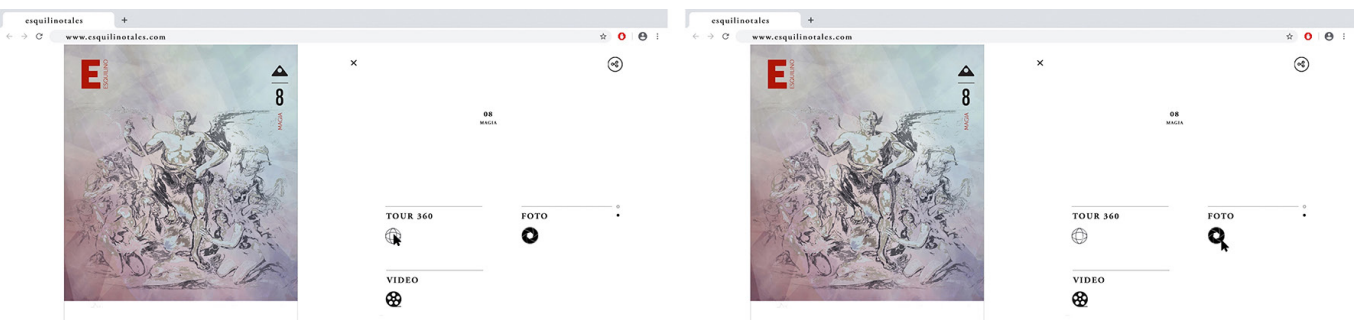

Casino Massimo Lancellot

Casino Massimo Lancellotti

$\stackrel{\text { viDEO }}{3}$
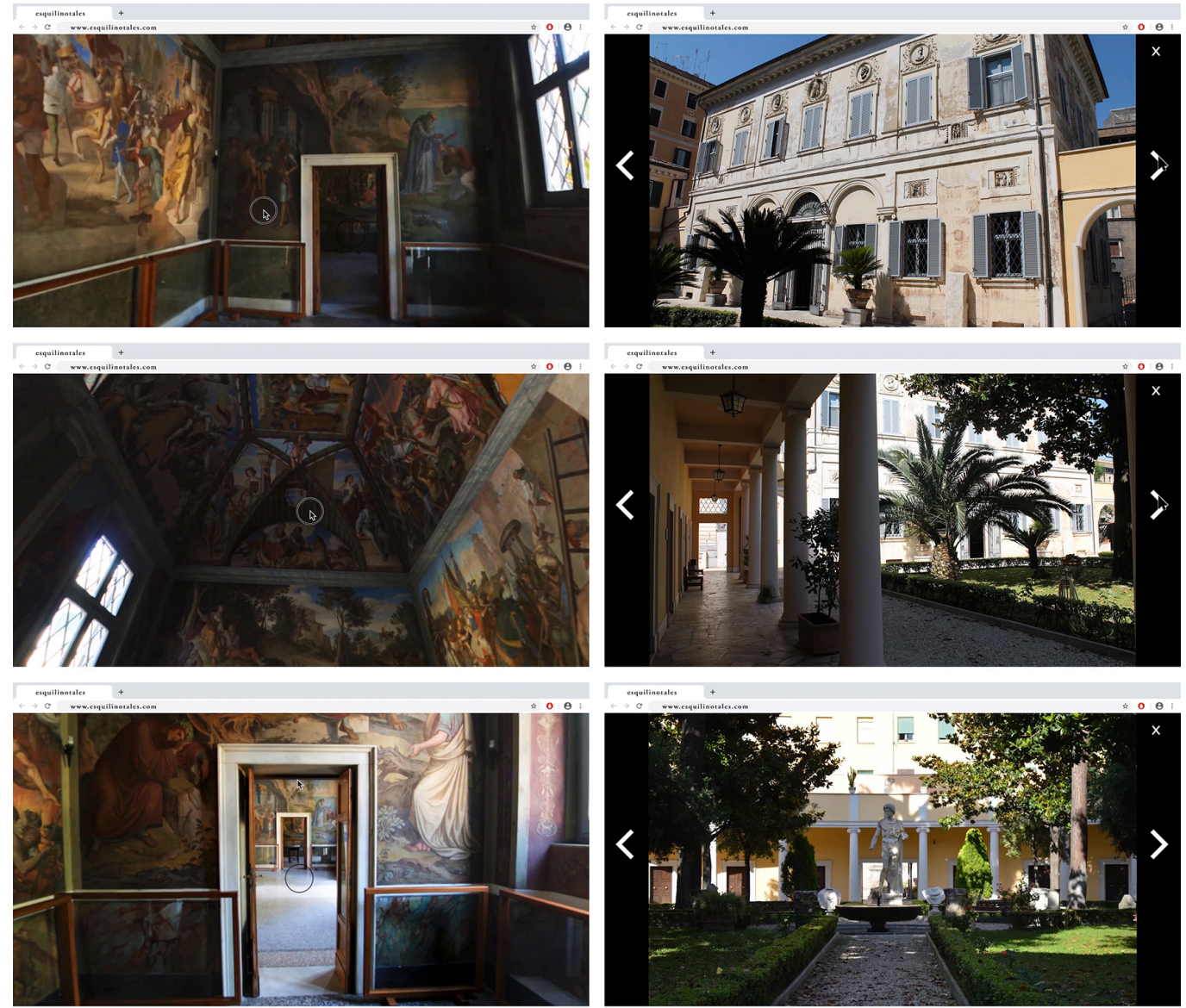

Fig. I I. L'esperienza The Esquilino Tales offerta dal sito: l'esplorazione del Casino Massimo

Lancellotti (realizzazione della carta di Simone Amarante). A sinistra alcune schermate del virtual tour (realizzazione di James Douch). A destra alcune schermate slide show fotografico (realizzazione di Simone Amarante, James Douch e Federica Giannoni)
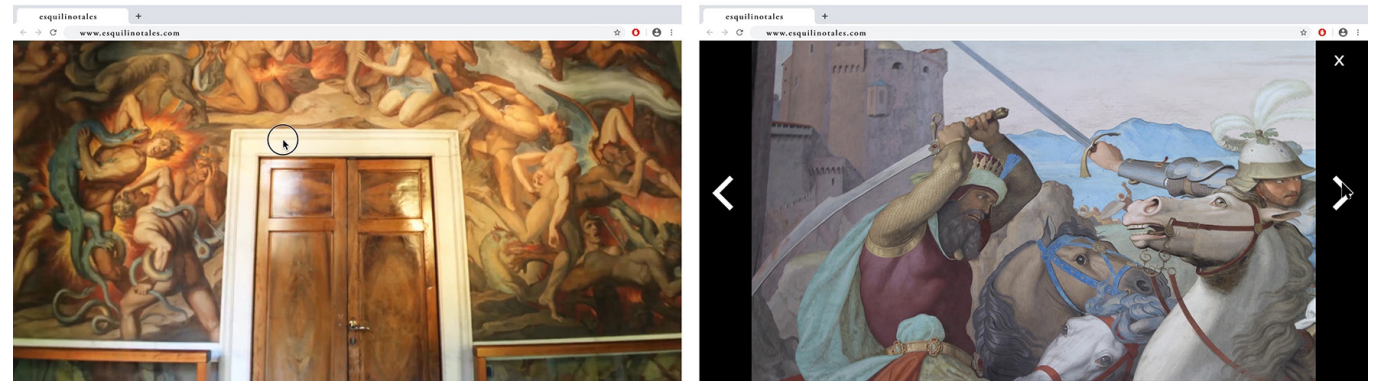

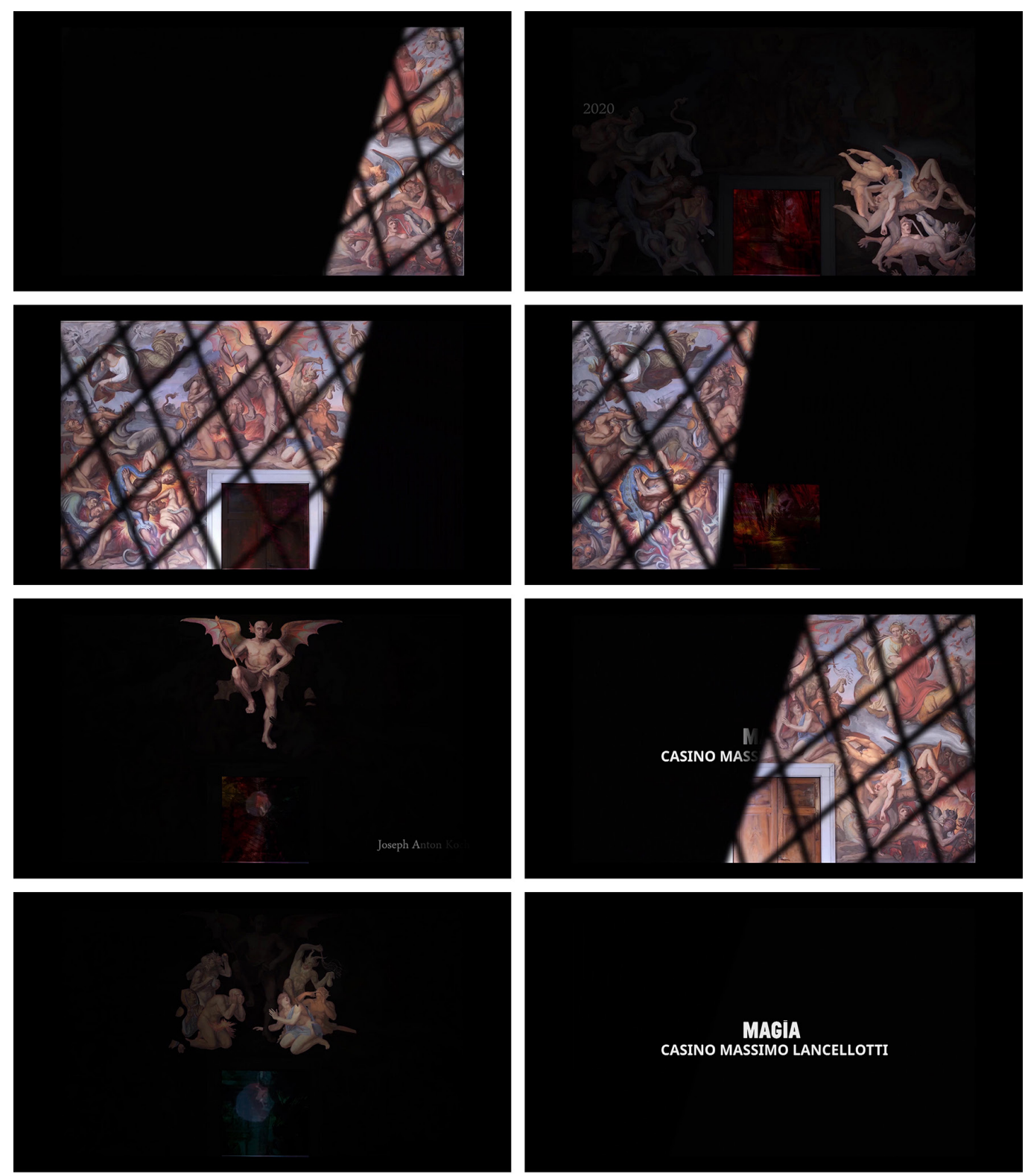

Fig. 12. L'esperienza The Esquilino Tales offerta da sito: l'esplorazione del Casino Massimo Lance lotti (realizzazione della

carta di Simone Amaran-

te). Alcune schermate de video (realizzazione di Simone Amarante)
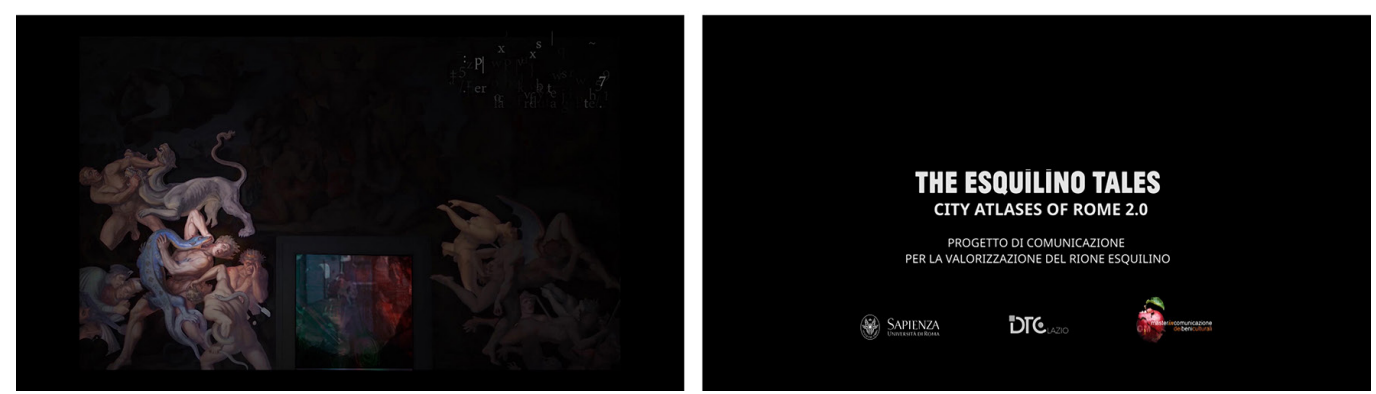
Per la composizione del verso delle carte le scelte grafiche sono state omogenee a quelle appena descritte: i quattro semi disposti agli angoli della carta, ma in grigio, su uno sfondo dall'aspetto simile a quelli utilizzati sul recto ma con una tonalità di colore che non interferisse con questi e, infine, una combinazione di cerchi e quadrati per circoscrivere lo spazio in cui posizionare il QR code per l'accesso ai contenuti multimediali, che sono resi disponibili in forma di testo o immagine - iconografie, fotografie, panorami navigabili, brevi video (fig. 9). Ai diversi tipi di contenuti è assegnato un differente ruolo nella narrazione: il video introduce alla storia e stabilisce una relazione empatica con il giocatore in modo da 'catturarlo' al gioco, i panorami sferici offrono una visita parzialmente immersiva e interattiva attraverso gli hot spot, le immagini iconografiche e fotografiche presentano una rassegna delle principali caratteristiche dei luoghi mentre i testi ne sottolineano i caratteri e ne raccontano fatti e avvenimenti. La struttura per link attraverso il QR code consente di mantenere vivo l'interesse per il gioco attraverso un costante e continuo aggiornamento dei contenuti, messo a punto da curatori esperti e una redazione.

Curatori e redazione la cui interfaccia è nella rappresentazione di sintesi offerta dalla home page del sito dove una grafica animata, costruita in analogia al retro delle carte, presenta al giocatore 40 piccole circonferenze che ruotano assecondando il profilo di una circonferenza più grande. Cliccando su ognuna delle piccole circonferenze si accederà in modo randomico alla singola carta da cui, dopo la presentazione testuale dell'esperienza, si potrà passare ai diversi contenuti selezionando l'icona corrispondente (figg. 10-12).

Con The Esquilino Tales la sfida è stata quella di tenere insieme luoghi fisici e luoghi virtuali, attraverso le interfacce/rappresentazioni immaginati e come i nuovi agorà dove attivare le connessioni tra visitatori, esperti e bene culturale. Un sistema di rappresentazioni da cui partire per esplorare l'Esquilino mescolando passato e presente, memorie monumentali e storia recente, romanità e multiculturalità, locale e globale, inclusione ed esclusione, stile architettonico e indeterminatezza spaziale.

Rappresentazioni con registri figurali diversi (immagini statiche, grafiche, fotografiche e in movimento) organizzate come un Atlante, dove l'Atlante è uno strumento attraverso cui decostruire la realtà, riconfigurarla e comunicarla come giustapposizione di frammenti di memorie.

The Esquilino Tales è perciò una 'macchina per pensare' per quel meccanismo immaginativo che si attiva riconoscendo nelle rappresentazioni che via via si succedono un'indefinibile prossimità e affinità, cioè quella certa "aria di famiglia" [Settis 2017, p. 97]. Una "macchina per pensare' che, in anni difficili in cui sembra impossibile conciliare singolare e molteplice, identità e collettività, offre l'insieme dei possibili sguardi sull'Esquilino proponendosi di ricostruire la topografia di una città immaginabile, ma tangibile, che tiene insieme memoria e futuro.

\section{Note}

[I] L'esperienza è stata condotta con gli studenti del Master in Comunicazione dei Beni Culturali della Sapienza Università di Roma, attivato dal Dipartimento di Storia, Disegno e Restauro dell'Architettura e dalla Facoltà di Architettura. Hanno collaborato all'esperienza i proff. Leonardo Paris, Cristian Farinella, Lorena Greco e Stefano Volante.

[2] L'esperienza è stata presentata ad uno degli incontri laboratoriali organizzati all'interno del progetto-mostra Riscatti di Città. La rigenerazione urbana a Roma, Palazzo Merulana, svoltosi tra il 18 gennaio e il 17 febbraio 2020.

[3] Tra i diversi motivi quello dell'impegno economico indispensabile alla realizzazione di un video-gioco con ambientazioni che producano un coinvolgimento emozionale che possa competere con quanto abitualmente sul mercato, come ad esempio dimostrano le edizioni di Rome Video Game Lab che si svolgono annualmente dal 2018. Ma più in generale siamo convinti con quanto affermato da Alessandro Baricco, "il Game è un habitat molto difficile, che offre intensità in cambio di insicurezza, genera disuguaglianze e non è adatto a un sacco di gente" [Baricco 20 I 8, p. 196].

[4] Tra i diversi tipi di giochi da tavolo analizzati: quelli di percorso - gioco dell'oca, Taboo ecc. - di fortuna e statistica - Risiko, Monopoli ecc. -, astratti - scacchi, dama, backgammon, ecc.

[5] Diversi sono stati i riferimenti, dalle carte napoletane e francesi a quelle collezionabili Magic: The Gathering, oppure la piattaforma gaming Gris (sviluppato da Nomada Studio con la regia di Conrad Roset) e il gioco in 2D a scorrimento laterale Father and son (ideato dal prof. Ludovico Solima dell'Università degli Studi della Campania "Luigi Vanvitelli" per il Museo Archeologico di Napoli MANN, con la supervisione scientifica del direttore Paolo Giulierini, e sviluppato dall'Associazione Tuo Museo dal game designer Fabio Viola). 


\section{Riferimenti bibliografici}

Baricco Alessandro (20।8). The Game. Torino: Einaudi.

Bray Massimo (20 I 3). II turismo e l'incontro tra beni culturali e territorio. <http://www.massimobray.it/il-turismo-e-lincontrotra-beni-culturali-e-territorio/.

Bruno Giuliana (2006). Atlante delle emozioni: in viaggio tra arte architettura e cinema. Milano: Bruno Mondadori. (Edizione italiana a cura di Maria Nadotti, 2006).

Desvallées André, Mairesse François (2010) (a cura di). Concetti chiave di museologia. Parigi: A. Colin. International Council of Museums. (Edizione italiana, 2016).

Huizinga Johan (1939). Homo Ludens. Amsterdam, 1939. Dalla traduzione telematica a cura di Rosaria Biondi, Nadia Ponti, Giulio Cacciotti, Vincenzo Guagliardo (casa di reclusione - Opera). <Ustaticl.I.sqspcdn.com > static > Johan_Huizinga_-_ Homo_ludens>.

Ippoliti Elena, Casale Andrea (2018). Rappresentare, comunicare, narrare. Spazi e musei virtuali tra riflessioni e ricerche. In Luigini Alessandro, Panciroli Chiara (a cura di). Ambienti digitali per l'educazione all'arte e al patrimonio. Milano: Franco Angeli, pp. $128-150$.

Ippoliti Elena, Albisinni Piero (20 I 6). Virtual Museums. Communication and/Is Representation. DisegnareCon, 9 ( I 7), pp. EI -E I 5.

Mangani Giorgio (2007). Introduzione alla riedizione del Teatro del mondo di Abramo Ortelio (Venezia I724). In L'Universo, a. LXXXVII, n. 6, 2007, supplemento. Firenze: Istituto Geografico Militare. <http://nuke.giorgiomangani.it/Studiesaggi/tabid/472/ Default.asp $>$.

MiBACT (20I4). Organizzazione e funzionamento dei musei statali. Decreto 23 dicembre 2014 (Decreto Musei).

Mottola Molfino Alessandra (2007). Museo (voce). In Treccani, Enciclopedia Italiana - VII Appendice. <http://www.treccani.it/ enciclopedia/museo_res-8I d7560 I-9bc2-I l e2-9d I b-0027I042e8d9_(Enciclopedia-Italiana)/ >.

Ragonese Ruggero (20I0). Guide turistiche: un'introduzione. In EIC Serie Speciale. Journal online of AISS - Associazione Italiana di Studi Semiotici, anno IV, n. 6, pp. 5- 18. Giannitrapani Alice, Ragonese Ruggero (a cura di). Guide Turistiche spazi, percorsi, sguardi.

Rogers Fred, Sharapan Hedda B. (1994). How children use play. In Education Digest, 59(8), pp. I3-I6.

Settis Salvatore (2002). Italia S.p.A. L'assalto al patrimonio culturale. Torino: Einaudi, 2002.

Settis Salvatore (20 I7). Un confronto tra Geburtstagsatlas e Mnemosyne Atlas:Tavola 7*. In La Rivista di Engramma, I5I, pp. 96-I00. Centanni Monica, Fressola Anna (a cura di). Mnemosyne contesa. ISSN I826-90IX.

UNESCO (2003). Convention for the Safeguarding of the Intangible Cultural Heritage. <https://ich.unesco.org/en/convention>.

UNESCO (2015). Recommendation concerning the Protection and Promotion of Museums and Collections, their Diversity and their Role in Society. <http://umac.icom.museum/wp-content/uploads/2018/08/24633 I m.pdf>.

\section{Autori}

Elena Ippoliti, Sapienza Università di Roma, elena.ippoliti@uniroma l.it

Andrea Casale, Sapienza Università di Roma, andrea.casale@uniromal.it

Per citare questo capitolo: Ippoliti Elena, Casale Andrea (2020). The Esquilino Tales. Comunicare, valorizzare, rigenerare/The Esquilino Tales. Communicating, promoting, regenerating. In Arena A., Arena M., Brandolino R.G., Colistra D., Ginex G., Mediati D., Nucifora S., Raffa P. (a cura di). Connettere. Un disegno per annodare e tessere. Atti del $42^{\circ}$ Convegno Internazionale dei Docenti delle Discipline della Rappresentazione/Connecting. Drawing for weaving relationships. Proceedings of the 42th International Conference of Representation Disciplines Teachers. Milano: FrancoAngeli, pp. 3383-34 I0. 


\title{
The Esquilino Tales. Communicating, Promoting, Regenerating
}

\author{
Elena Ippoliti \\ Andrea Casale
}

\section{Abstract}

This essay presents The Esquilino Tales, developed with students in the Master in Communication of Cultural Goods at the Sapienza University of Rome. The goal is to enhance the varied, even distinctive, complexity of the Esquilino area, the XV Rione of Rome. Since this is a place where both the whole and its individual parts are recognizable first as 'figures', the project began with the conviction that an effective proposal could only start from the specific signs of the places. The experimentation therefore investigated the practices of representation, upgrading them with the techniques of storytelling, gamification, and storydoing with the aim of developing a communication strategy within a wide range of graphical/visual languages. In this strategy, active means of exploration such as initial enhancement and urban-regeneration activities are initiated between visitors/citizens and the Esquilino area/city to begin to redeem our city.

Keywords

graphic languages, representation of city, gamification, storytelling, storydoing.

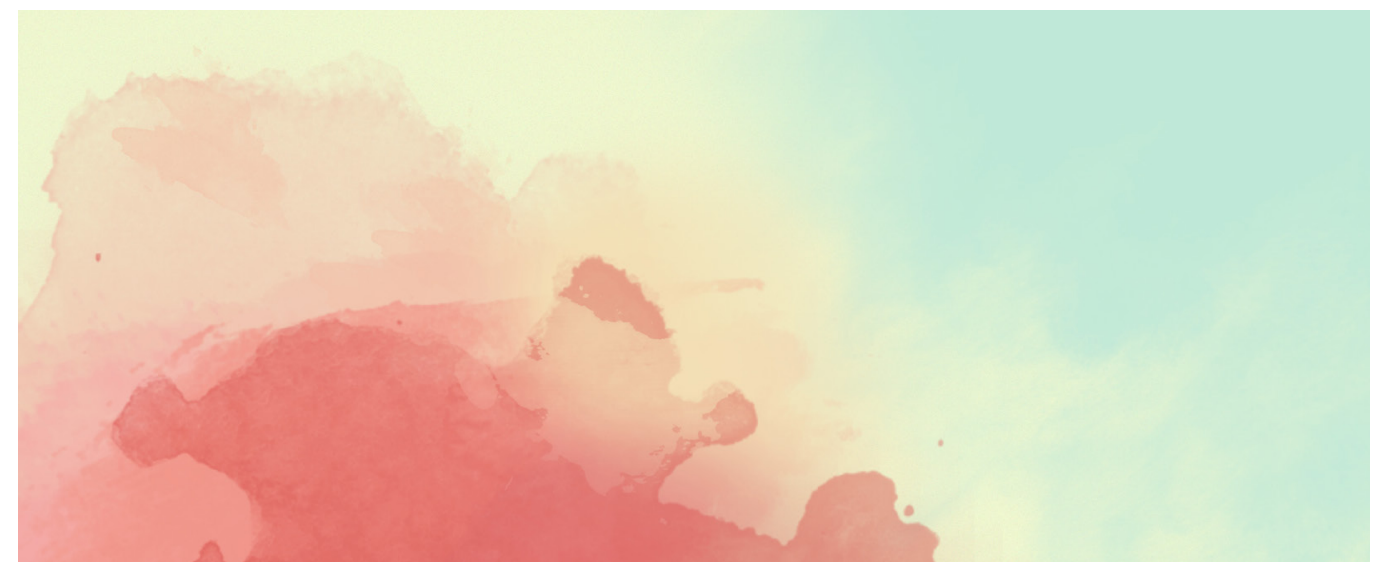




\section{Premise}

What makes the Italian cultural heritage truly unique is its "continuum between monuments, cities, and citizens" because, according to an interpretation by Salvatore Settis, it is precisely in that extraordinary continuum between 'high' works and the cities' connective fabric housing them that "our most precious cultural good" is found [Settis 2002, p. 10, translated by the authors].

This profound awareness about Italy has, since cultural good was defined, considered the heritage -tangibile and intangible- as a systemic good, that is, an expression of the set of qualitative and quantitative connections among the individual goods and between these goods and the given context. This idea of systemic heritage also gave rise to a culture of enhancement "in which the value of each individual monument or object of art results not from its isolation, but from its insertion within a vital context" [Settis, 2002, p. I5, translated by the authors].

This awareness is party to the profound renewal that, particularly in recent years [MiBACT 20 I 4], has regarded museums, their mission, and the basic role that they can play in promoting education and scientific progress, cultural and natural diversity, sustainable development, and intercultural dialogue [UNESCO 20 I5]. Said renewal has regarded both 'objects' in the 'collection' [Desvallées, Mairesse 2010, p. 26] and museum spaces, expanding the former and dilating the latter for a renewed understanding of practices and knowledge, the cultural places connected to them, and the communities recognized in that cultural heritage [UNESCO 2003]. The view of these museums is therefore aimed outside, re-evaluating the diffuse cultural heritage in cities and the communities living there through the 'diffuse museum' [Mottola Molfino 2007]. With this particular type of museum, it is even more necessary to address the system, i.e. the connections, to design "paths of meaning that are well focused on specific territorial areas such that ... it does not simply mean summarizing a series of works of art or monuments, but translating them into a historically and culturally consistent path or many parallel" [Bray 20 I3, translated by the authors].

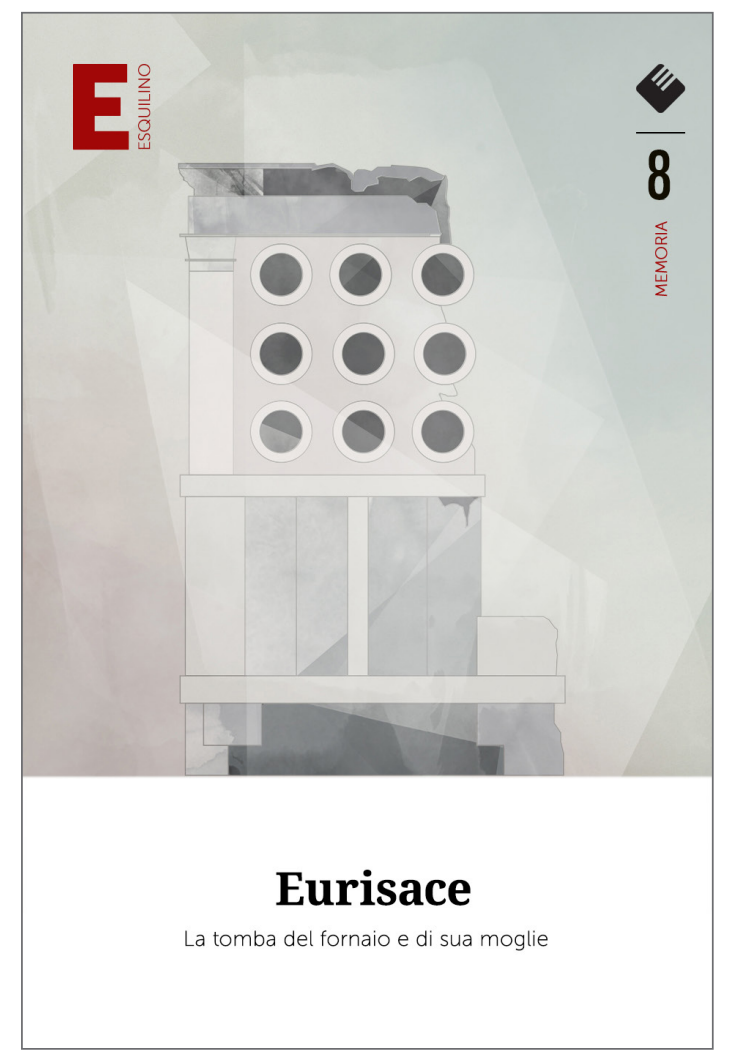


Fig. 2. Some representative cards of the Magia perspective: "The snow at Santa Maria Maggiore. Every 5 August, the miracle of the snow" (created by Simone Amarante): "Ambra Jovinelli Theatre. Liberty style architecture in the heart of the Esquilino district" (created by Simone district" (created by Simone Amarante) and "Palazzo Masserspective: Palazzo Massimo alle Terme. Within, it houses classic art of Rome" (created by Federica Giannoni);"'Basilica of the Holy Cross in Jerusalem. Houses the relics of Christ's Cross" (created by Simone Amarante).

Promoting the communication of these goods therefore means working with the possible connections using a mechanism that is at heart very similar to 'modern' guides, which, since the first half of the 1800s, freed the greater public, allowing them to individually and independently plan their own trips. These are particular devices wherein, without an author, the places offered to the 'reader/traveler' come to the fore by means of possible itineraries [Ragonese 2010] and where the plot woven between places and the traveler generates a travel experience, whether real or virtual [Mangani 2007]. 'Modern' guides did not invent this mechanism; rather, it derived from the varied ways in which the inhabited space is given a shape -atlases, maps, itineraries etc.- which were more recently renewed by cinema [Bruno 2006].

It is in the framework of these reflections that the project The Esquilino Tales [I] was developed. The project aims to enhance the varied, even distinctive, complexity of the Esquilino area, the XV Rione of Rome, experimenting with different forms and accepted meanings in which it is possible to refine representation and its related connections.

Since the project relates to goods that fall under the extended definition of 'architecture', where both the whole and its individual parts are therefore recognizable first as 'figures', the project began with the conviction that a proposal for its effective use could only start with the specific signs of the places. The experimentation therefore investigated the practices of representation, upgrading them with the techniques of storytelling, gamification, and storydoing to develop a communication strategy within a wide range of graphical/visual languages. In this strategy, active means of exploration such as initial enhancement and urban-regeneration activities are initiated between visitors/citizens and the Esquilino area/city to begin to redeem our city [2].

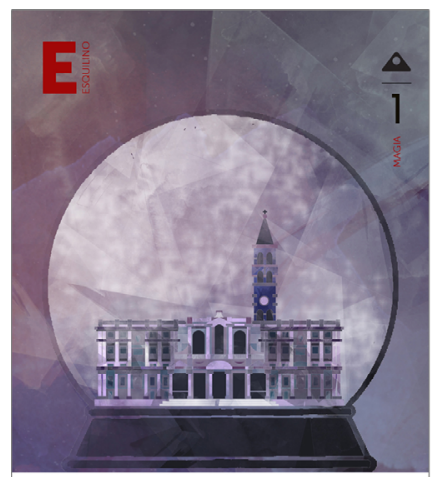

La neve a Santa Maria Maggiore ogni 5 agosto il miracolo della nero

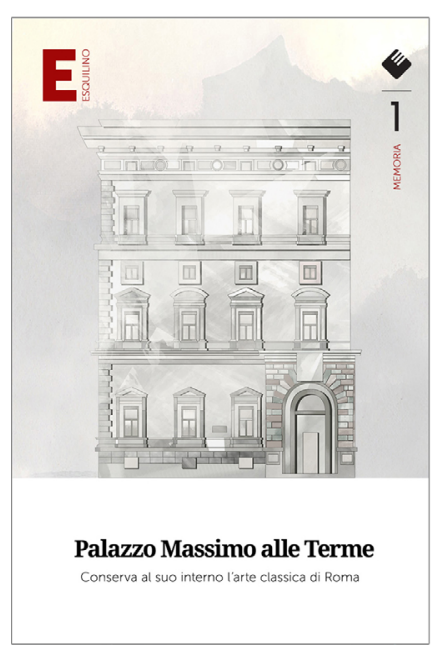

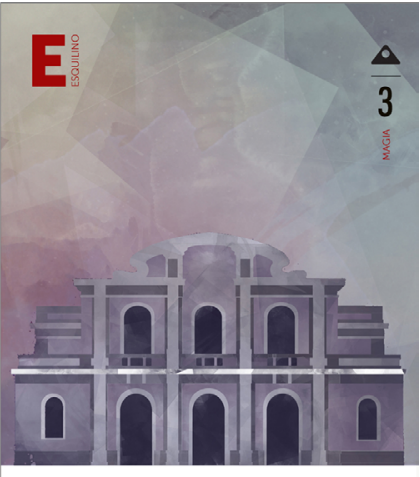

Teatro Ambra Jovinelli
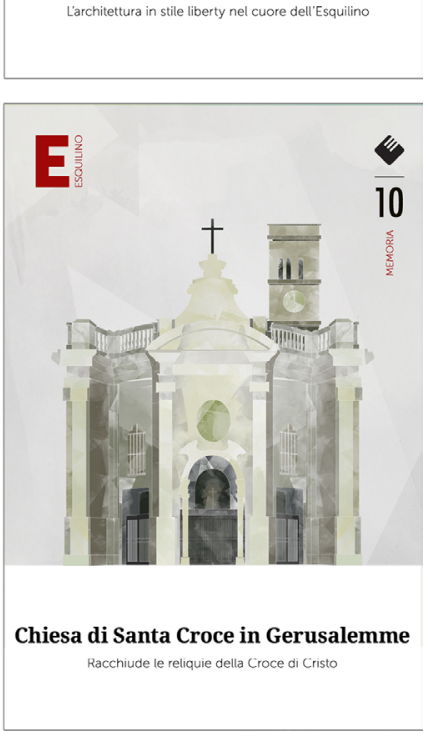
Fig. 3. Some representative cards of the Passaggio perspective: "Termini Station. Where Rome meets the world" (created by Federica Giannoni); "Porta Maggiore. Monumental aqueduct and gate of Rome" (created by Angel Moschetti) and the Contaminazione perspective The dinosaur of Termini Station. Bizarre names for modern architecture" (created by Simone Amarante):" Obelisks. Elegant crossroads in the urban layout of Rome" (created by Margherita Stisi).
In our opinion, this experience falls entirely under the more general area of 'city representations', a particular family of representations that presents an extremely wide range of types and variations, running the entire range of representational conventions -from figures to signs, from concepts to plausibility - all of which are similar because they are emotional devices. This emotional capacity to suggest histories and interpretations is still present in city representations, albeit with forms that have changed and undergone innovation due to new media.
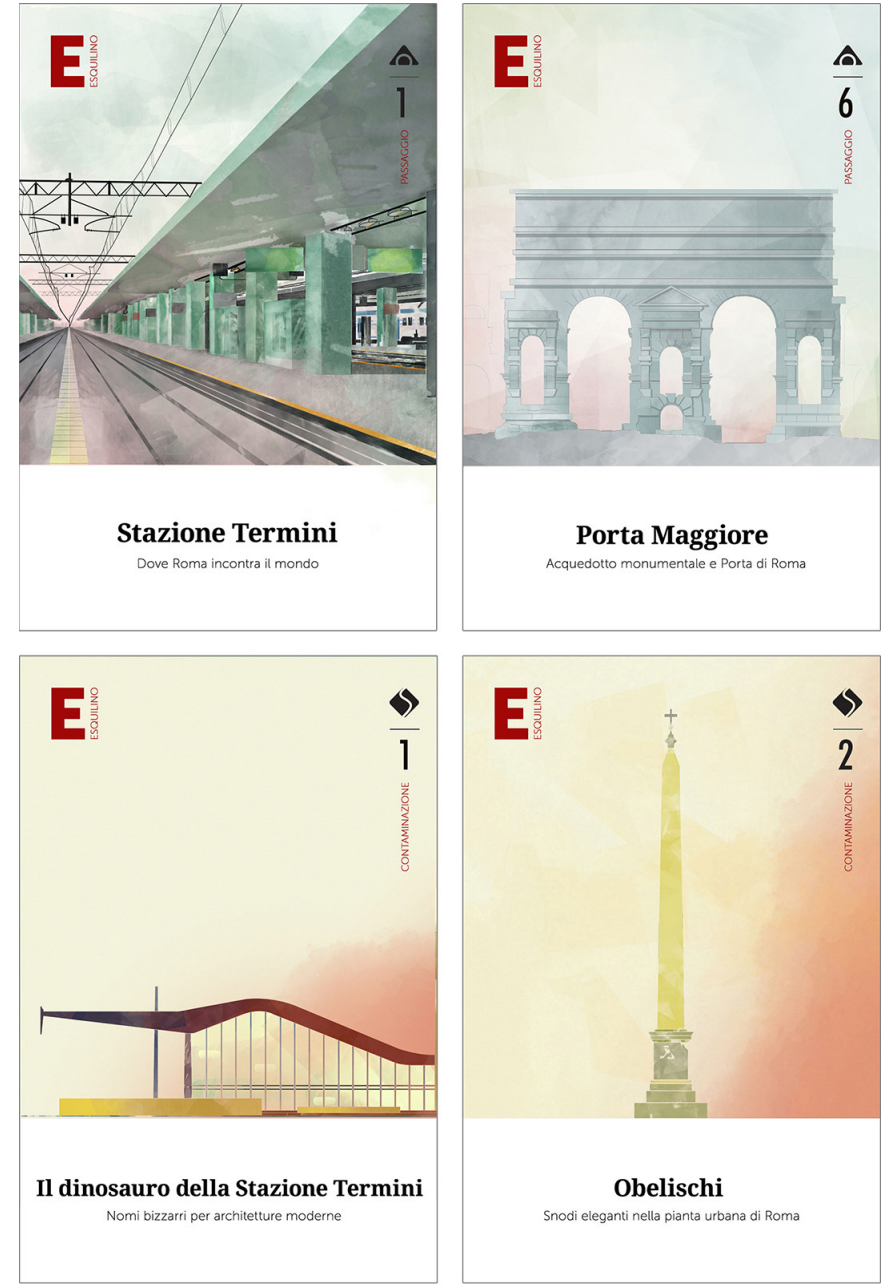

\section{The Esquilino Tales: The Game}

In 2020, Rome, the capital of Italy, will celebrate its I50th anniversary. This anniversary has given rise to the diffuse museum communication project The Esquilino Tales, dealing with the Rione where an entire neighbourhood was built in order to adapt the city, which then had little more than 200.000 residents, to its role as the capital of a country.

The game provides the opportunity to explore an area that houses important historical remains, from the thousand-year history of the eternal city to the more recent history of Italy. The Esquilino area is characterized by the density of places of historic, architectural, archaeological, cultural, social, and emotional prestige and, although it lies in the centre of Rome, it is mostly unknown, not only to tourists, but also to residents in Rome. This is a layered reality that throughout history has known how to reconfigure itself to adapt to growth and physical transformation and to subsequent migration and globalization, connoted by a variety of both built space and the people living there: a multitude of cities rather than just one city. 
On the one hand, this complex, heterogeneous reality is impossible to describe from only one point of view. On the other, synthetic, involved communication that induces the 'visitor' to active participation is needed. Both aspects pointed to the technique of gamification as the structure used to anchor the communication project.

Some recent experimentation related to the communication of cultural goods has shown how games can also be an effective way for users to approach the heritage. The emotional environment of the game, initiating an interactive relationship, facilitates learning processes because "Play is a very serious matter [...] It is an expression of our creativity; and creativity is at the very root of our ability to learn, to cope, and to become whatever we may be" [Rogers, Sharapan 1994, p. 13]. As educators know well, nothing is more serious than play,

Fig. 4. The various initia tests and references: Neapolitan and French playing cards (above) collectible Magic: The Gathering cards, (middle), the gaming platform Gris (bottom) also applied to the tomb of Eurisace.
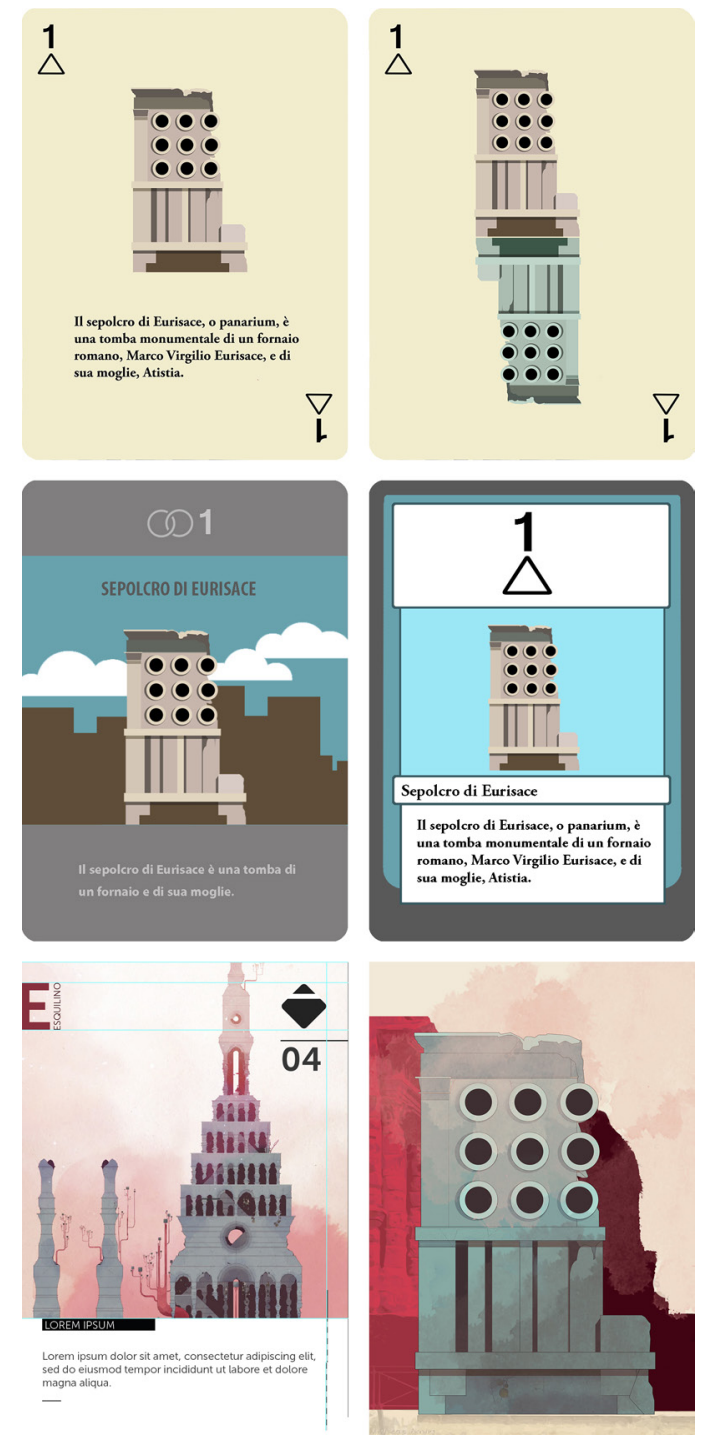

which is indispensable for individuals and also the community, "due to the 'sense' that it contains, the meaning, the expressive value, and the spiritual and social ties that it creates, that is, essentially as a cultural" [Huizinga, 1939, p. 7, translated by the authors].

To select the type of game, video games were discarded for various reasons [3] and after an analysis of the most common table games [4], the choice fell to collectible game cards. As recently demonstrated, these combine the methods of play with the passion for collection, a particular connection that lends a capacity to spread virally, that is, to self-promote itself. 
The concept of the communication project entails each urban reality being described in a set of 40 cards (deck) organized into four families ( 10 numbered cards) referring to a particular thematic narrative (itinerary). While only experimenting with the Esquilino district, the project is designed to be replicated and appropriately customized for different urban areas equipped with recognizable characteristics, a condition that also favours the game's spread through the 'proliferation' of decks of cards. This simple structure and its related connections -card/family/ deck/decks- thereby transforms the cards into collector objects. Their easy spread and competition between players, which lies at the basis of any game, give a further push for interaction due to the need for exchange.
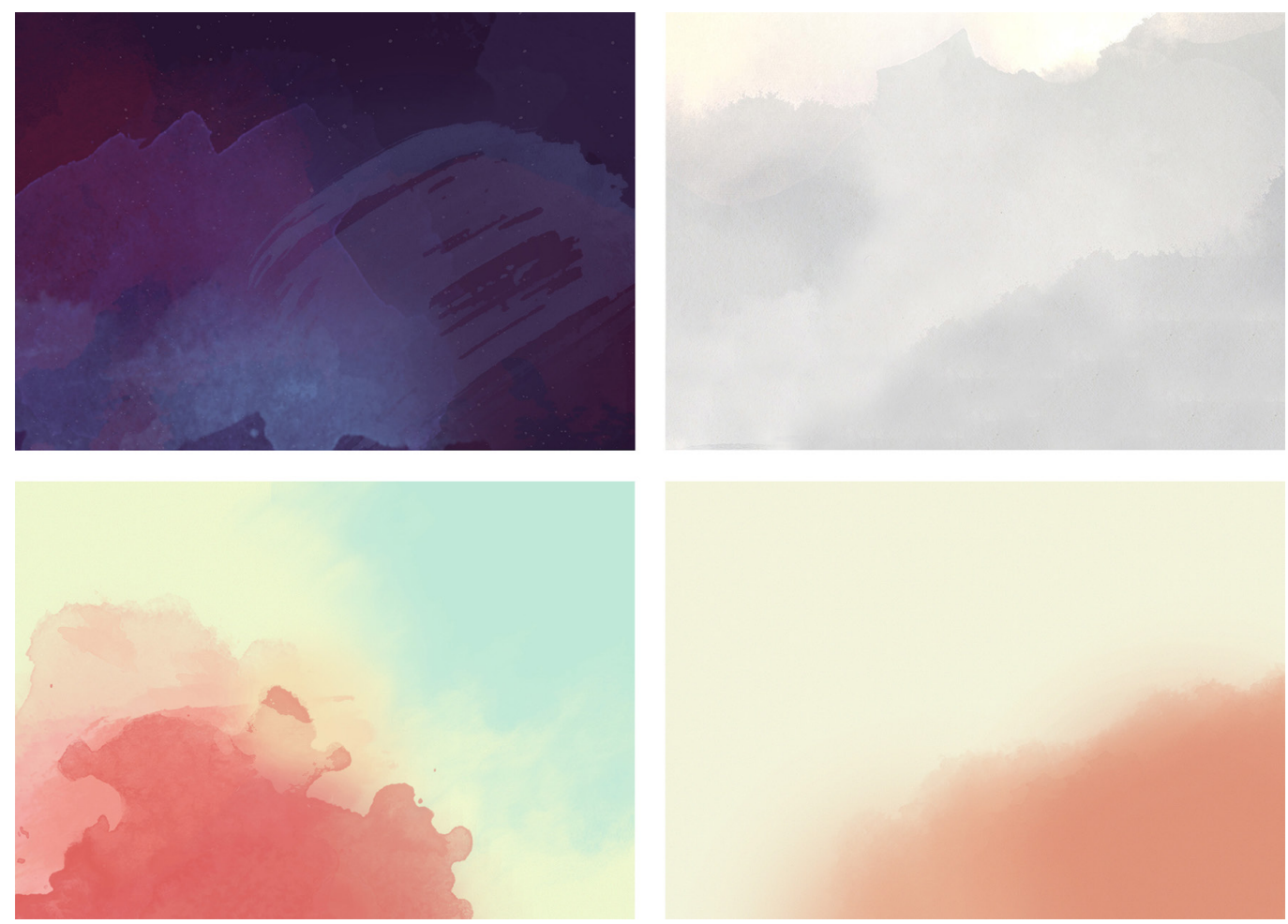

To favour the experience of visiting the cultural heritage housed in cities, the rules of the game require players to increase the power of their cards when they interact with a cultural element, entailing progressive increases in power according to the different means of access and actions: at a distance (QR code, app, or website), directly through a tour, completing an itinerary from among those proposed, etc. Once the objective has been fixed, players can thereby implement different strategies to earn power individually or as a team by interacting with the cultural good. The rules of the game require players to personalize each game, establishing some variations in the deck to complete, modifying the default composition by replacing individual cards while keeping the number and families fixed. 

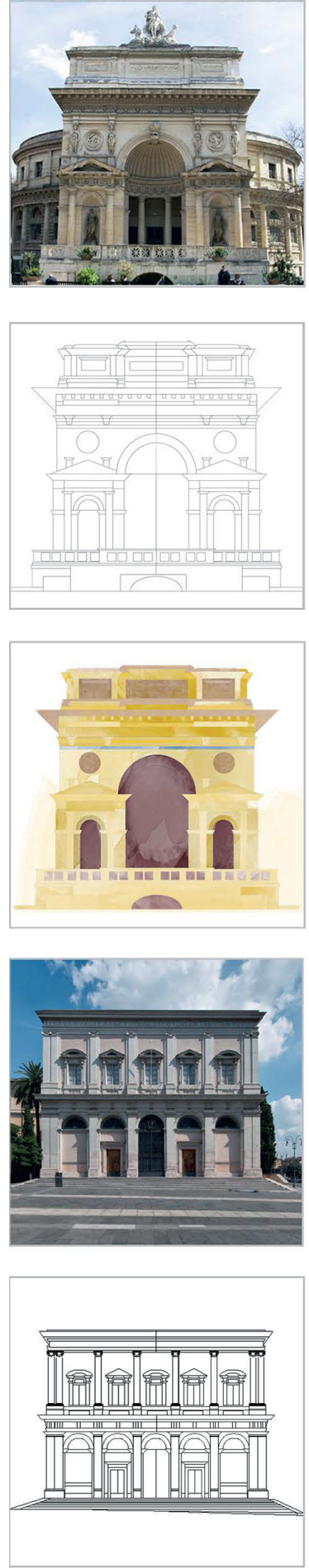

Fig. 6. The procedure to build the cards:

'figure' starting from the phen thion through retracing an some particular and some particular 'brushstrokes', followed by insertion in the

background of the visual.

'Aquario romano and the

Roman Aquarium and

the Lateran Holy Stairs

(created by James

Douch).

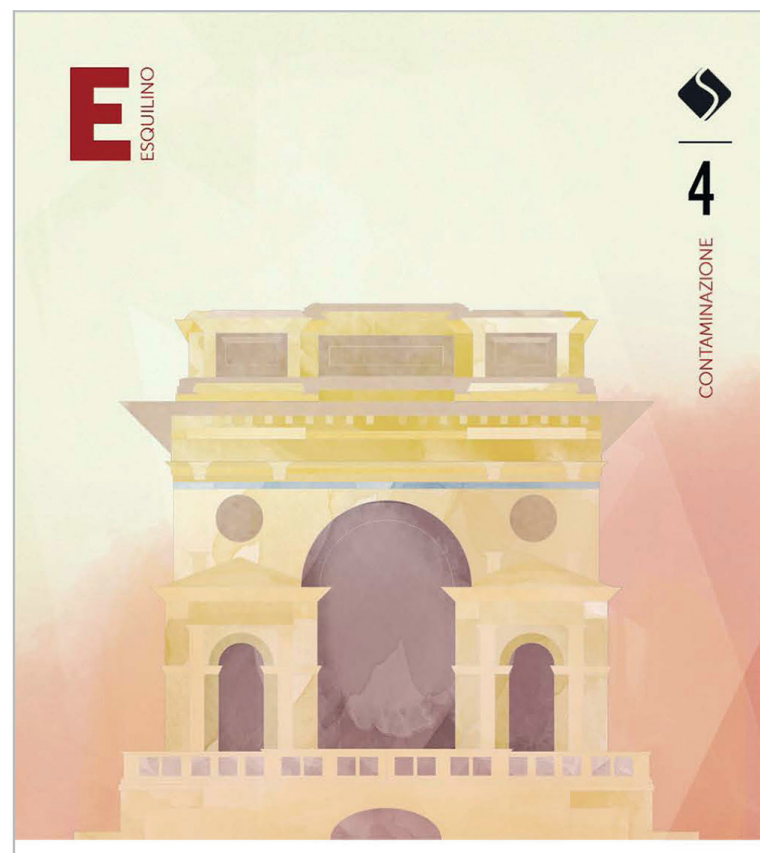

\section{Acquario romano}

La sfortunata disavventura di un edificio che

voleva essere parigino

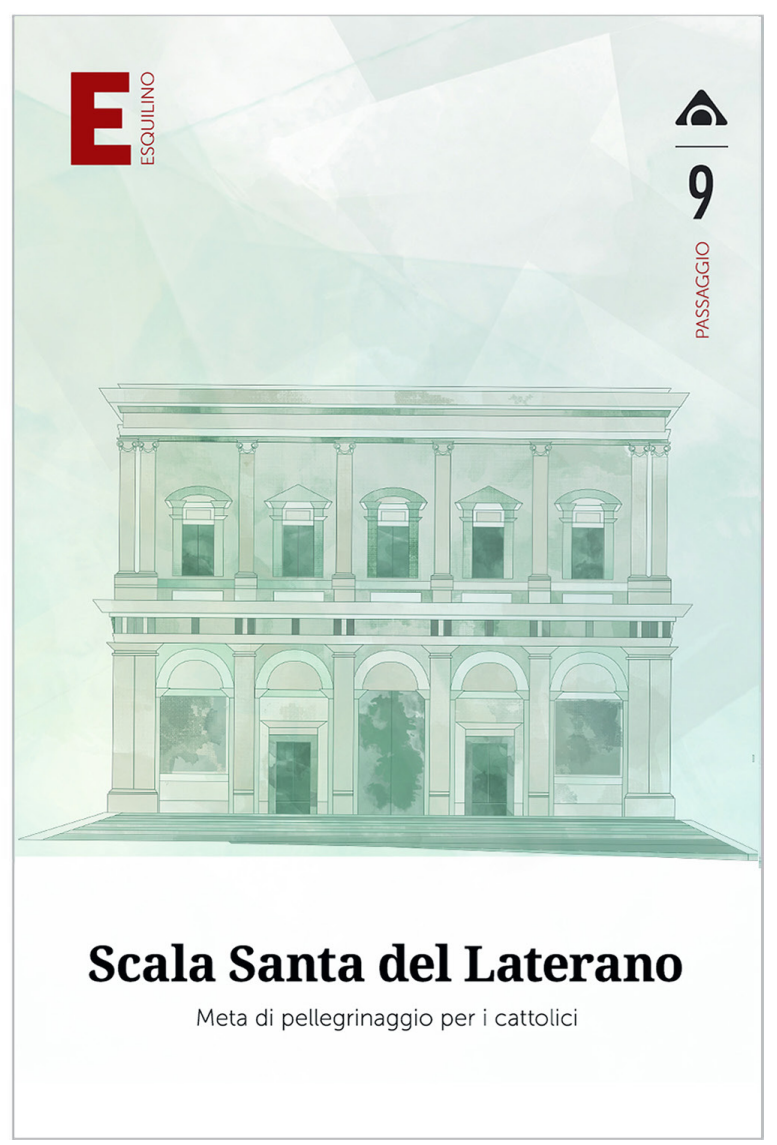




\section{The Esquilino Tales: The System of Representation}

While the fulcrum of the project lies in the individual card (analogous in its digital version with the role of interface to access the cultural content (fig. I), the game is structured so that one would preferably discover the Esquilino district following the cards in a family, that is, via one of the four particular perspectives of reading proposed in each deck. Each perspective creates a connection between the individual points of interest (places and histories that they summarize) described by each card to compose a specific itinerary.

Therefore, after careful analysis of the tangible and intangible heritage of the Esquilino distri$\mathrm{ct}$, the four perspectives according to which the points of interest are grouped are: Magia [Magic], Memoria [Memory], Passaggio [Transition], and Contaminazione [Fusion] (figs. 2, 3). As can be easily understood, these perspectives represent categories and qualities with a level of generalization such that they may be used effectively to describe other urban areas. More than being related to a particular 'object', they refer to a particular 'experience' that can be had by crossing urban places: an unexpected view, the dreamlike aspect of past events, the fascination of a show or concert, aesthetic enjoyment of a work of art, the memory of an old history, the evocation of a recent history, the transition between one era and another made physically by crossing a city, a connection between apparently different places, the evidence of modern multiculturalism, the stratification that condenses an urban space, the perennial coexistence between sacred and secular, etc.

Once the structure of the game and the principal rules were defined, the graphical elements -figures, colours, backgrounds, symbols, characters, layout- were designed such that they worked together to orient players beginning a trip through The Esquilino Tales. Therefore, each place and its associated history is represented by a figure, while the visual narrative (Magia, Memoria, Passaggio, Contaminazione) is entrusted both to the colour palette and a symbol (suit).
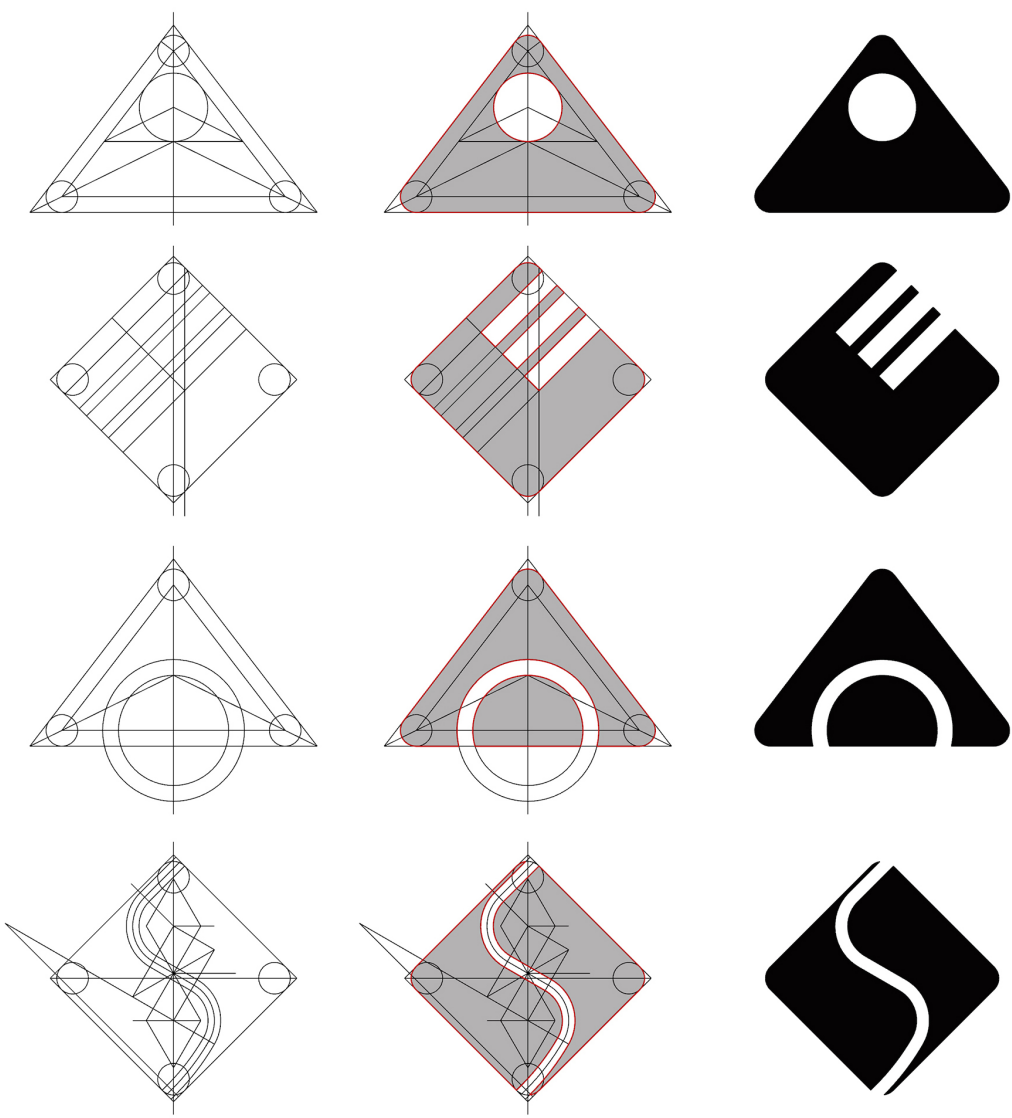
For the figures, the goal was to define a recognizable style. After some experimentation [5] (fig. 4), it was decided that these figures should be borderless and emerge from the juxtaposition of mostly regular geometric shapes. Only flat colour tones, selected from within the same chromatic tonality would be used, simulating the use of watercolour with different brush sizes in the digital environment. The next step was to associate a prevalent chromatic tone with each of the narrative perspectives (violet/blue for Magia, grey for Memoria, green/ teal for Passaggio, orange/ochre for Contaminazione), followed by development of the four corresponding backgrounds (fig. 5). These were characterized by soft, sinuous forms that, except for minor modifications, were adopted for all cards pertaining to the same family (fig. 6).

The next step was to design the graphics of the different suits (fig. 7). An ideogrammatic stylization was chosen to express the four perspectives, each of which was characterized by iconographic uniformity with respect to shape (triangle, square, circle, and rounded corners) and colour (black).

Following this, for the purposes of orienting the player, the layout was defined for the arrangement of the graphical elements in the compositional space of the cards, which measure 8 $\mathrm{cm} \times 12 \mathrm{~cm}$ (fig. 8). On the front, the upper left contains the 'E' and the text 'Esquilino', which are balanced on the right by the suit, the card number, and the name of the perspective. The space is divided vertically into two parts: above, the figure is situated on the background, while below there is a white band that contains the name of the place, centred (bold serif font of a size designed to be read easily), along with a subtitle that hints at the history (sans serif characters of a notably smaller size).
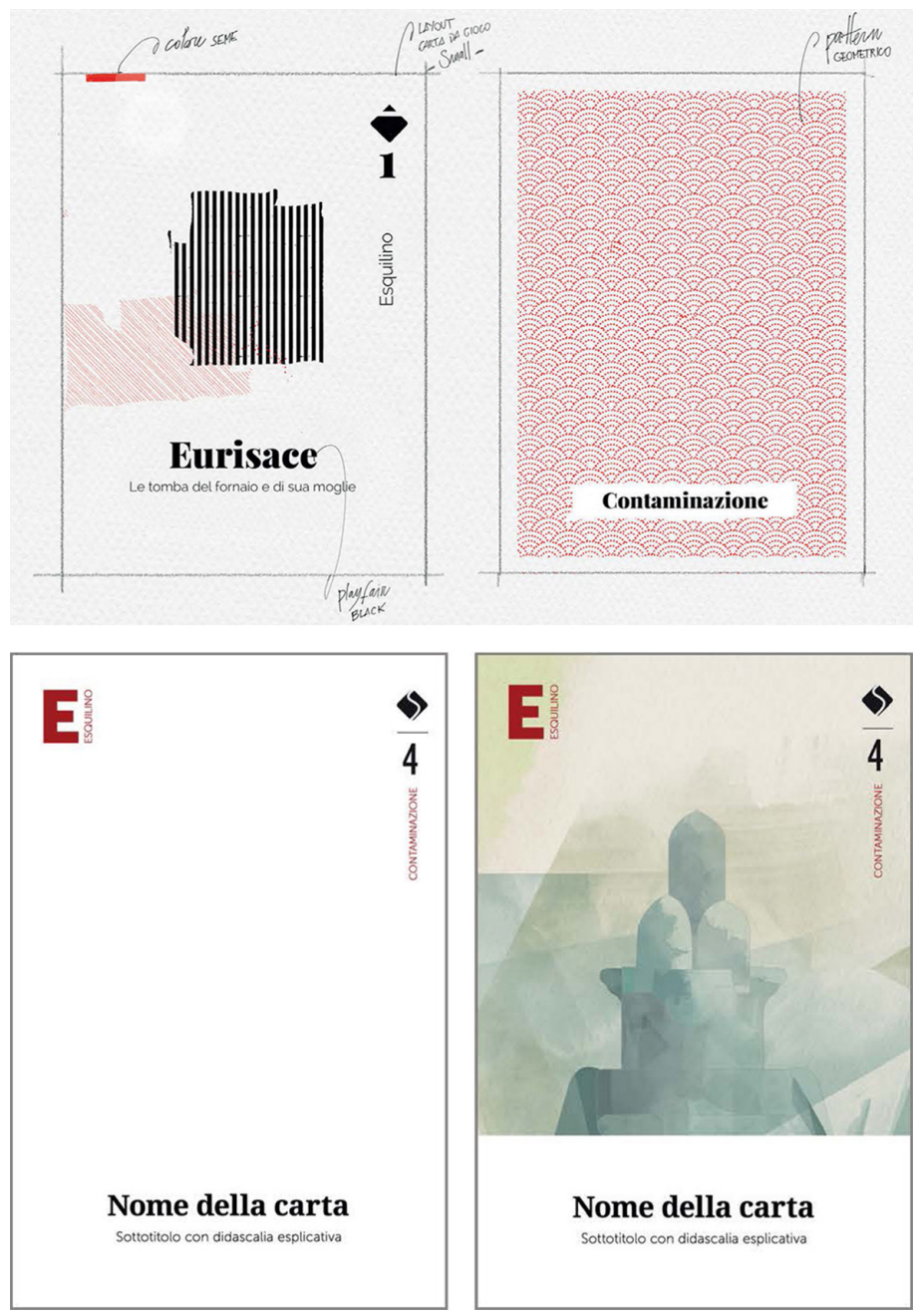


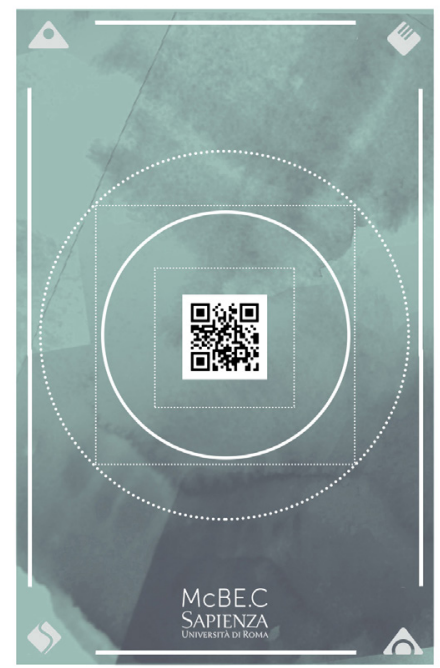

Fig. 10. Summary representation of The Esquilino Tales: the home page of the website. From top to bottom and from left to right: after animation similar to a slot machine in which the four suits of the families/visuals appea and which ends with the title The Esquilino Tales in the centre, one can access a dedicated page in the footer, in which the data and information are cummarized or begin are sumerized begin the experience. By clickng one of the small circles of the wheel, the player randomly accesses a card and, after the textual presentation of the experience, the player can move to different content $\left(360^{\circ}\right.$ tour, photographic slide show video) by selecting the corresponding icon. The design of the website was created in particular by Simone Amarante,

with James Douch and

Federica Giannoni.
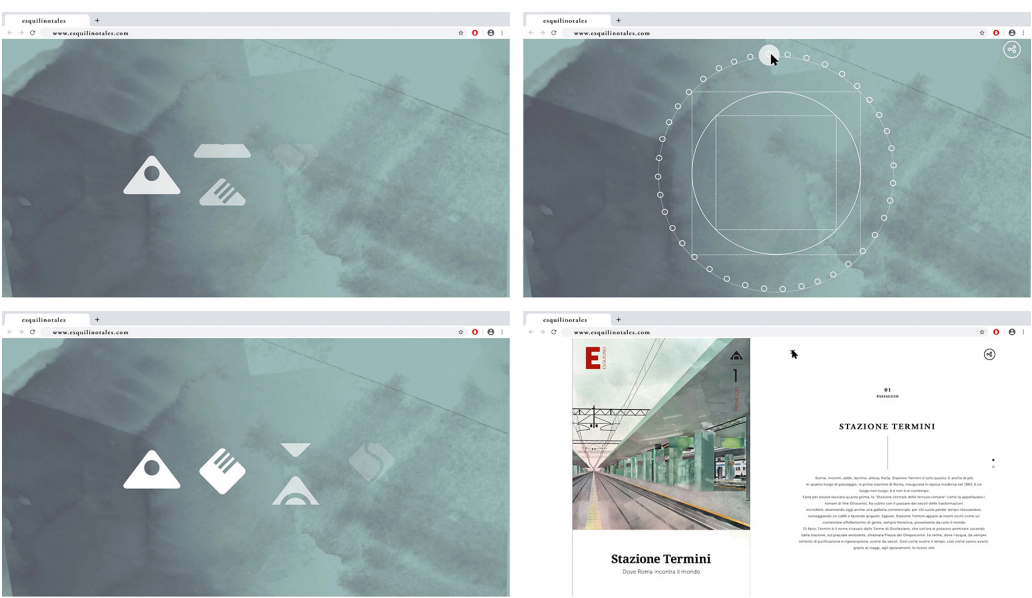

Stazione Termini
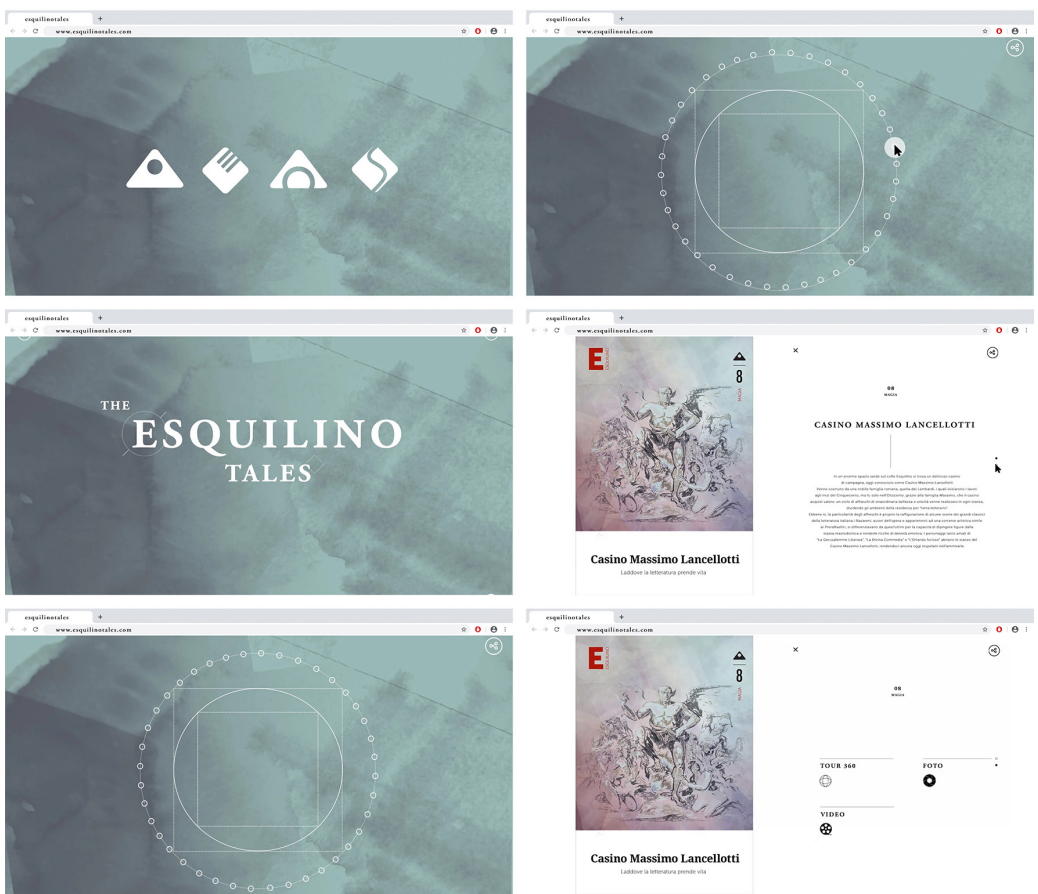

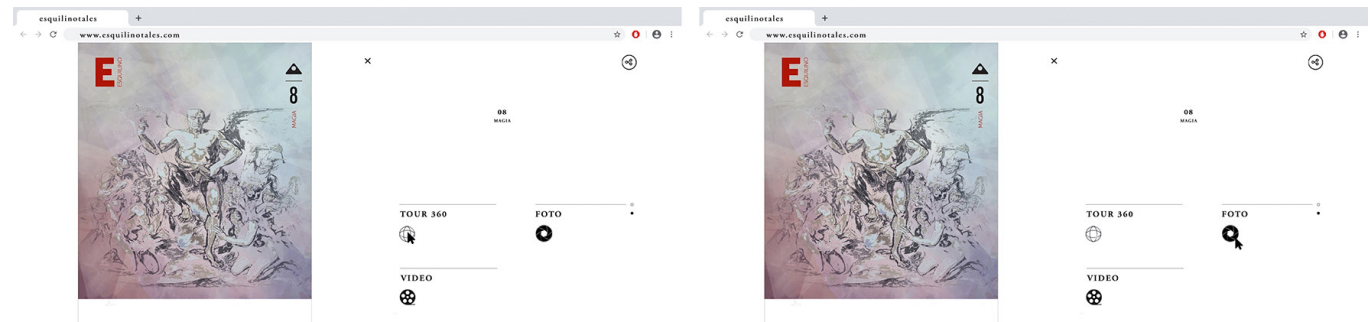

Casino Massimo Lancellot

Casino Massimo Lancellotti
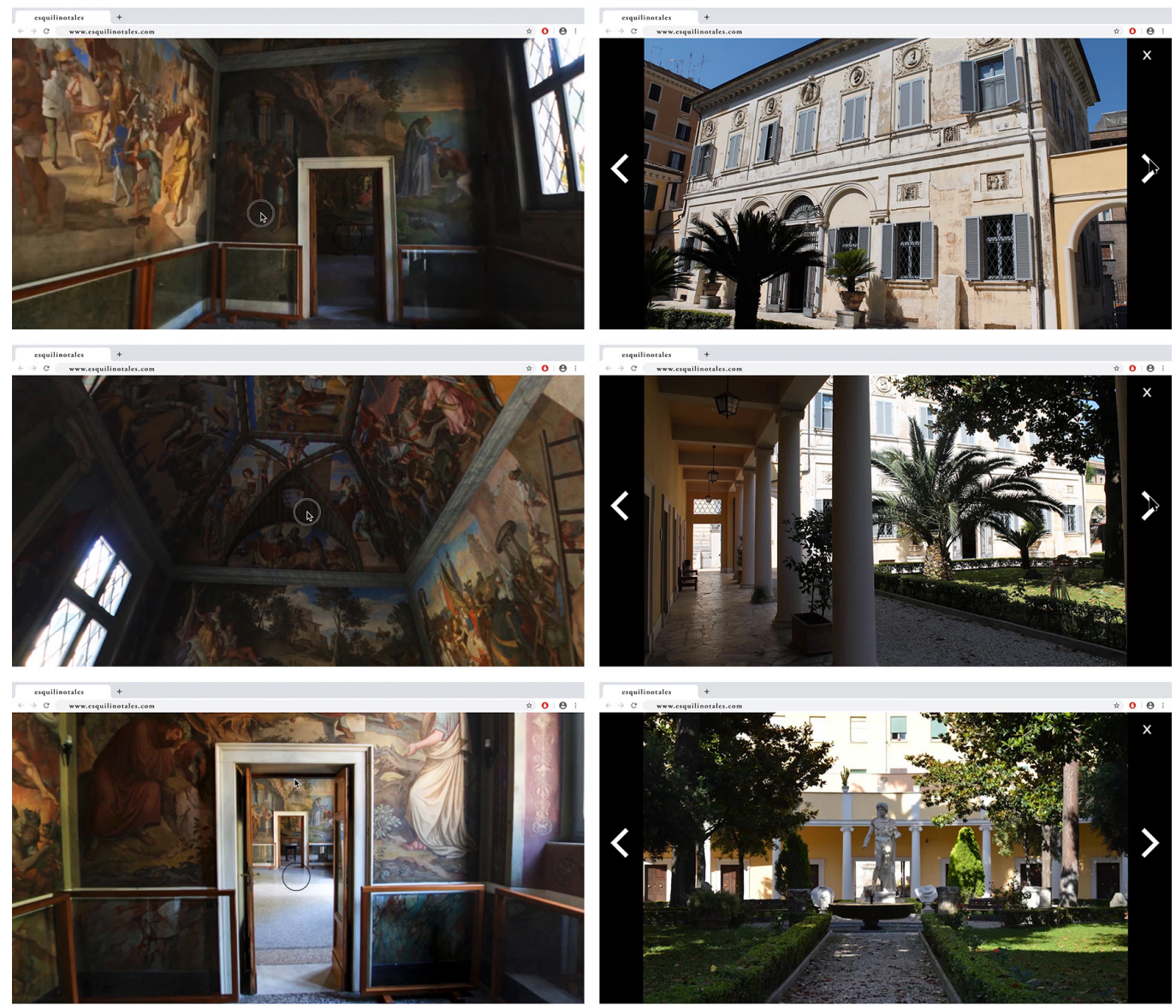

Fig. 1 I. The experien-

ce The Esquilino Tales

offered by the website:

exploration of the Casino

Massimo Lancellotti

(card created by Simone

Amarante). Left, some screenshots from the

virtual tour (created by

James Douch). Right

some screenshots from

the photographic slide

show (created by Simone

Amarante, James Douch,

and Federica Giannoni).
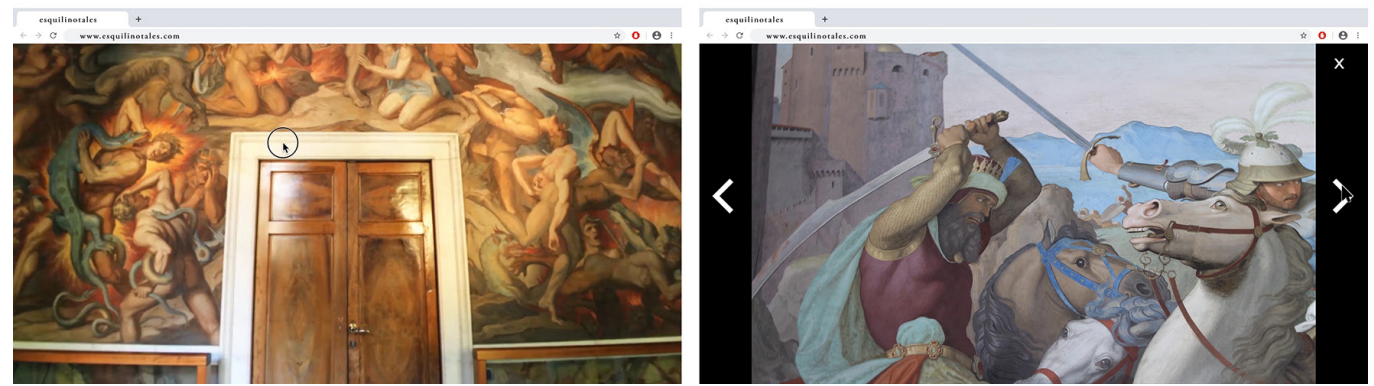

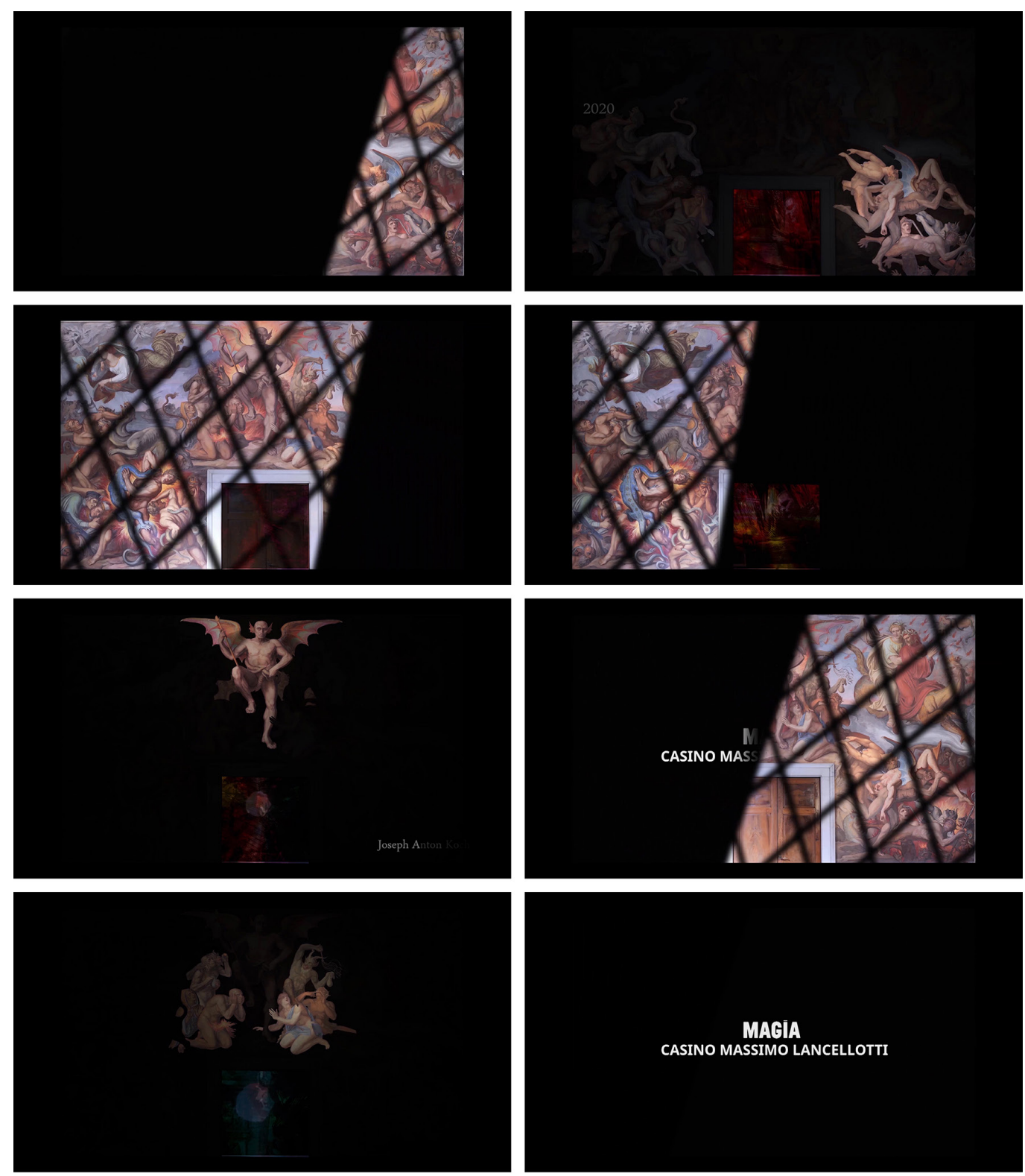

Fig. 12. The experien-
ce The Esquilino Tales

offered by the website:

exploration of the Casino

Massimo Lancellotti (card

created by Simone Ama-

rante). Some screenshots

of the video (created by

Simone Amarante).
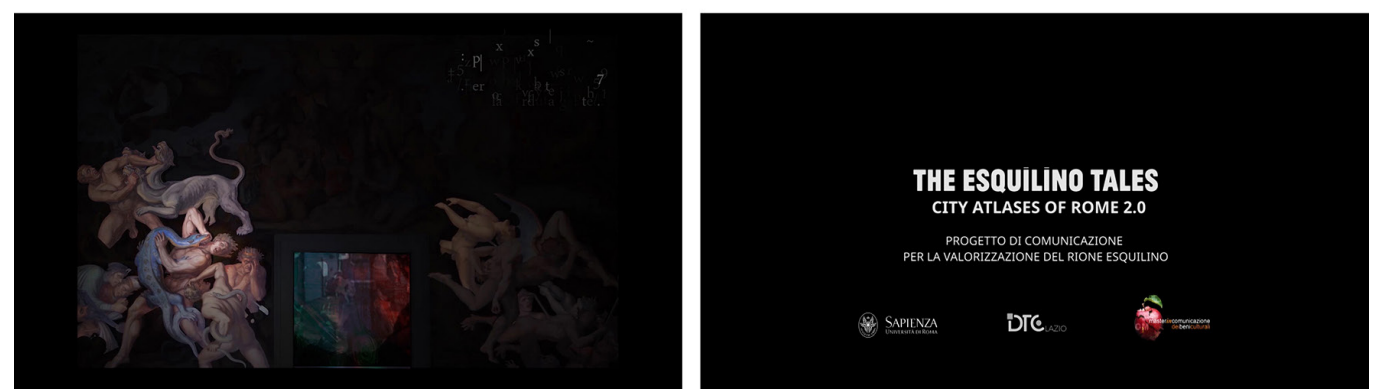
For the back of the cards, the graphical choices were consistent with those described above (fig. 9). The four suits appear in grey at the corners of the card on a background similar to the one on the front, but with a complementary colour tone. Finally, a combination of circles and squares circumscribes the space containing the QR code, which is used to access multimedia content available in the form of text or images - iconography, photographs, panoramas to be navigated, brief videos.

The different types of content are assigned different roles in the narration.Videos introduce the history and create an empathic relationship with players in order to 'capture them' in the game. Spherical panoramas offer a partially immersive and interactive tour via hot spots. The iconography and photographic images present a summary of the main characteristics of the places, and the texts underline the characteristics and relate facts and events. The structure of links through the QR code allows interest in play to be maintained through constant, continuous updating of the content, implemented by expert curators and editorial staff. Their interface lies in the representation of summaries on the home page of the website, where an animated graphic, built in analogy with the back of the cards, presents the player with 40 small circles that rotate on the path of a larger circle. By clicking on one of the small circles, the player randomly accesses an individual card. After the textual presentation of the experience, the player can move on to different content by selecting the corresponding icon (figs. 10-12).

With The Esquilino Tales, the challenge was to hold physical and virtual places together through the interfaces/representations imagined as new agorae where connections could be made between visitors, experts, and cultural goods. Such a system of representations is a start to exploring the Esquilino district, mixing past and present, monumental memories and recent history, life in Rome and multiculturalism, local and global, inclusion and exclusion, architectural style and spatial indeterminacy. The representations encompass different registers of figures (static images, graphics and photographs, and moving images) organized like an atlas, where the atlas acts as a tool for deconstructing reality, reconfiguring it and communicating it as the juxtaposition of fragments of memories.

The Esquilino Tales is therefore a 'machine for thinking' due to that imaginative mechanism that is activated when recognizing an undefinable proximity and affinity, giving it a certain 'air of family' "aria di famiglia" [Settis 2017, p. 97]. When it seems impossible to reconcile single and multiple, identity and community in certain years, this 'machine for thinking' aims to re-

\section{Notes}

[I]The experience was carried out with students in the Master in Communication of Cultural Goods at the Sapienza University of Rome, begun by the Department of History, Design and Restoration of Architecture and the School of Architecture. Collaborating in the experience were Leonardo Paris, Cristian Farinella, Lorena Greco, and Stefano Volante.

[2] The experience was presented at one of the laboratory encounters organized within the project/show Riscatti di Città. La rigenerazione urbana a Roma [Redeeming the City. Urban Regeneration in Rome], Palazzo Merulana, held between 18 January and 17 February 2020.

[3] The various reasons include the economic resources necessary to create a video game with a setting that would produce emotional involvement and could compete with what is currently on the market, as demonstrated, for example, by the editions of Rome Video Game Lab that have been held annually since 2018. More in general, we are convinced by what Alessandro Baricco says, "Game is a most difficult habit; it offers intensity in exchange for insecurity, generates inequalities, and is not suitable for a lot of people" [Baricco 2018, p. 196, translated by authors].

[4] The different types of board games analysed include: 'path' games - snakes and ladders, Taboo, etc. - luck and statistics games - Risk, Monopoly etc. - abstract games - chess, checkers, backgammon, etc.

[5] Different references range from Neapolitan and French playing cards to collectible Magic: The Gathering cards, as well as the gaming platform Gris (developed by Nomada Studio and directed by Conrad Roset) and the 2D side-scrolling game Father and Son (created by Ludovico Solima at the Luigi Vanvitelli University of Campania for the National Archaeological Museum of Naples, with scientific supervision by director Paolo Giulierini and development by Tuo Museo by the game designer Fabio Viola). 


\section{References}

Baricco Alessandro (2018). The Game. Torino: Einaudi.

Bray Massimo (20 I 3). II turismo e l'incontro tra beni culturali e territorio. <http://www.massimobray.it/il-turismo-e-lincontrotra-beni-culturali-e-territorio/.

Bruno Giuliana (2006). Atlante delle emozioni: in viaggio tra arte architettura e cinema. Milano: Bruno Mondadori. (Edizione italiana a cura di Maria Nadotti, 2006).

Desvallées André, Mairesse François (2010) (a cura di). Concetti chiave di museologia. Parigi: A. Colin. International Council of Museums. (Edizione italiana, 2016).

Huizinga Johan (1939). Homo Ludens. Amsterdam, 1939. Dalla traduzione telematica a cura di Rosaria Biondi, Nadia Ponti, Giulio Cacciotti, Vincenzo Guagliardo (casa di reclusione - Opera). <Ustaticl.I.sqspcdn.com > static > Johan_Huizinga_-_ Homo_ludens>

Ippoliti Elena, Casale Andrea (2018). Rappresentare, comunicare, narrare. Spazi e musei virtuali tra riflessioni e ricerche. In Luigini Alessandro, Panciroli Chiara (a cura di). Ambienti digitali per l'educazione all'arte e al patrimonio. Milano: Franco Angeli, pp. $128-150$.

Ippoliti Elena, Albisinni Piero (20 I 6). Virtual Museums. Communication and/Is Representation. DisegnareCon, 9 ( I 7), pp. EI -E I 5.

Mangani Giorgio (2007). Introduzione alla riedizione del Teatro del mondo di Abramo Ortelio (Venezia I724). In L'Universo, a. LXXXVII, n. 6, 2007, supplemento. Firenze: Istituto Geografico Militare. <http://nuke.giorgiomangani.it/Studiesaggi/tabid/472/ Default.asp $>$.

MiBACT (20I4). Organizzazione e funzionamento dei musei statali. Decreto 23 dicembre 2014 (Decreto Musei).

Mottola Molfino Alessandra (2007). Museo (voce). In Treccani, Enciclopedia Italiana - VII Appendice. <http://www.treccani.it/ enciclopedia/museo_res-8 I d7560 I-9bc2-I l e2-9d I b-0027| 042e8d9_(Enciclopedia-Italiana)/>.

Ragonese Ruggero (20I0). Guide turistiche: un'introduzione. In EIC Serie Speciale. Journal online of AISS - Associazione Italiana di Studi Semiotici, anno IV, n. 6, pp. 5- 18. Giannitrapani Alice, Ragonese Ruggero (a cura di). Guide Turistiche spazi, percorsi, sguardi.

Rogers Fred, Sharapan Hedda B. (1994). How children use play. In Education Digest, 59(8), pp. I3-I6.

Settis Salvatore (2002). Italia S.p.A. L'assalto al patrimonio culturale. Torino: Einaudi, 2002.

Settis Salvatore (20 I7). Un confronto tra Geburtstagsatlas e Mnemosyne Atlas:Tavola 7*. In La Rivista di Engramma, I5I, pp. 96-I00. Centanni Monica, Fressola Anna (a cura di). Mnemosyne contesa. ISSN I826-90IX.

UNESCO (2003). Convention for the Safeguarding of the Intangible Cultural Heritage. <https://ich.unesco.org/en/convention>.

UNESCO (2015). Recommendation concerning the Protection and Promotion of Museums and Collections, their Diversity and their Role in Society. <http://umac.icom.museum/wp-content/uploads/20।8/08/24633 I m.pdf>.

\section{Authors}

Elena Ippoliti, Sapienza Università di Roma, elena.ippoliti@uniroma I.it

Andrea Casale, Sapienza Università di Roma, andrea.casale@uniromal.it

To cite this chapter. Ippoliti Elena, Casale Andrea (2020). The Esquilino Tales. Comunicare, valorizzare, rigenerare/The Esquilino Tales. Communicating promoting, regenerating. In Arena A., Arena M., Brandolino R.G., Colistra D., Ginex G., Mediati D., Nucifora S., Raffa P. (a cura di). Connettere. Un disegno per annodare e tessere. Atti del $42^{\circ}$ Convegno Internazionale dei Docenti delle Discipline della Rappresentazione/Connecting. Drawing for weaving relationships. Proceedings of the 42th International Conference of Representation Disciplines Teachers. Milano: FrancoAngeli, pp. 3383-34I0. 